NBER WORKING PAPER SERIES

\title{
LOAN PROSPECTING AND THE LOSS OF SOFT INFORMATION
}

\author{
Sumit Agarwal \\ Itzhak Ben-David \\ Working Paper 19945 \\ http://www.nber.org/papers/w19945 \\ NATIONAL BUREAU OF ECONOMIC RESEARCH \\ 1050 Massachusetts Avenue \\ Cambridge, MA 02138
}

February 2014, Revised July 2017

Previously circulated as "Do Loan Officers' Incentives Lead to Lax Lending Standards?" We are grateful to Tobias Berg, Souphala Chomsisengphet, Harrison Hong, Naveen Khanna, Jose Liberti, Evgeny Lyandres, Mitchell Petersen, Rich Rosen, Kasper Roszbach, Antoinette Schoar, Amit Seru, René Stulz, Greg Udell, and Luigi Zingales for helpful comments. We wish to thank seminar participants at the University of California at Berkeley, FIRS 2012, the Fisher College of Business at The Ohio State University, the School of Public Affairs at The Ohio State University, the National University of Singapore, the NBER Behavioral Economics meeting, the NBER Risk of Financial Institutions meeting, the SIFR Conference on Real Estate and Mortgage Finance (Stockholm), Indiana University, the University of Maryland, the Tel-Aviv University Finance Conference, Dartmouth University, the University of Florida, the Wharton School of Business, New York University, Cornell University, the CEPR EBC Conference, the Western Finance Association meetings, the American Finance Association meetings, the ABFER Conference in Singapore, the Federal Reserve Bank of New York, and the Federal Reserve Bank of Chicago for comments. The views expressed herein are those of the authors and do not necessarily reflect the views of the National Bureau of Economic Research.

NBER working papers are circulated for discussion and comment purposes. They have not been peer-reviewed or been subject to the review by the NBER Board of Directors that accompanies official NBER publications.

(C) 2014 by Sumit Agarwal and Itzhak Ben-David. All rights reserved. Short sections of text, not to exceed two paragraphs, may be quoted without explicit permission provided that full credit, including $(\subset$ notice, is given to the source. 
Loan Prospecting and the Loss of Soft Information

Sumit Agarwal and Itzhak Ben-David

NBER Working Paper No. 19945

February 2014, Revised July 2017

JEL No. G01,G21

\begin{abstract}
$\underline{\text { ABSTRACT }}$
We study a controlled experiment in which a bank's loan officers were incentivized based on originated loan volume to encourage prospecting for new business. While treated loan officers did attract new applications, both extensive and intensive margins of loan origination expanded $(+31 \%$ new loans; loan size $+15 \%)$. We find that loan officers gave greater weight to hard information in approval decisions. Despite no change in the observable characteristics of approved loans, their default rate increased $(+24 \%)$. Finally, the bank's imputed credit-default model lost its predictive power. Overall, loan-prospecting incentives led to unfavorable soft information being overlooked in the origination process.
\end{abstract}

\author{
Sumit Agarwal \\ McDonough School of Business \\ Room 427 \\ Georgetown University \\ 3700 O Street NW \\ Washington, DC 20057 \\ ushakri@yahoo.com \\ Itzhak Ben-David \\ Department of Finance \\ Fisher College of Business \\ The Ohio State University \\ 2100 Neil Avenue \\ Columbus, OH 43210 \\ and NBER \\ bendavid@fisher.osu.edu
}




\section{Introduction}

In many financial institutions, loan officers are expected to source new loans ("loan prospecting") in addition to their traditional role of screening applications. Loan screening is a passive role that involves analyzing the risk of existing applications. By contrast, loan prospecting is an active role that requires loan officers to act as salespersons: they actively promote the bank's loan products. Banks typically reward loan officers for their efforts with a bonus that depends on the volume of originated loans (U.S. Bureau of Labor Statistics 2012).

Previous studies have proposed that expanding the scope of the loan officer's job may affect a bank's loan-origination process. Heider and Inderst (2012) study the theoretical effects of compensation for loan prospecting. In equilibrium, the increased competition in the credit market leads banks to rely primarily on hard information when approving loans. Because critical soft information is ignored, the quantity of approved loans increases but their quality declines. In a related study, Cole, Kanz, and Klapper (2015) investigate the effects of variable compensation on loan officers' approval decisions. They use an experimental setting implemented with a group of loan officers at a commercial bank in India, which allows them to study loan-approval patterns in response to different incentive schemes. They find that when origination volume is rewarded, loan officers are more likely to approve applications, and loan quality declines. Although these studies provide a broad view on the relation between compensation and the volume and quality of loans, we have no empirical evidence showing how loan prospecting affects the approval process.

In this study, we provide novel empirical findings about how loan prospecting transforms the bank's use of hard and soft information and the characteristics of its book of business. We analyze a controlled experiment conducted in the small business unit of one of the largest U.S. commercial banks ("the Bank"). Following competitive pressures in the industry, the Bank's 
management decided to expand the scope of about half of its loan officers' jobs to include loanprospecting activities, whereas the other half of the loan officers maintained a narrower scope of screening activities only. As in Bénabou and Tirole's (2016) "bonus culture" economy, loan officers who were assigned to the loan-prospecting group were compensated with bonuses that were based primarily on loan dollar volume. Our data include detailed information on both loan applications and approved loans, which allows us to study the approval process in great detail.

The pilot program we study took place in 2005. For many years, loan officers in the Bank focused on screening loans, and their compensation was based on a fixed salary. With the credit expansion of the early 2000s, the Bank's management decided in 2004 to encourage loan officers to seek new business, and to compensate them according to loan volume. This compensation arrangement was a common practice in the banking industry at the time (U.S. Bureau of Labor Statistics 2012). The pilot for the program was implemented the following year in the Bank's New England division for about half of the loan officers. The assignment of loan officers to their groups was determined by the legacy human resources computer system to which they belonged; loan officers could not switch between systems. Although loan officers' assignment was not random, we show that no significant difference existed in any attribute of applications or approved loans in the year preceding the experiment. Our data set contains loan details for more than 30,000 small business loan applications processed by more than 130 loan officers during the 24-month window around the change in the job scope of loan officers. We use a difference-in-differences design and within-loan-officer variation to detect causal effects of loan-prospecting incentives on the approval process.

The loan-prospecting program resulted in an expansion of $31 \%$ in the extensive margin (new borrowers) and 15\% in the intensive margin (larger loan amounts). We offer two hypotheses 
for what led to this expansion. The first is that loan officers worked to seek new business and therefore either increased the number of applications or increased their quality. Our tests, however, detect no increase in the number of applications or any improvement in their characteristics. To the detriment of the Bank's management, loan officers did not source new applications by accessing previously untapped pools of potential borrowers.

The second hypothesis is that the Bank changed the threshold at which credit was advanced. A credit-approval decision involves two inputs: hard information (observable to the econometrician) and soft information (unobservable) (Petersen 2004). In our analysis, we examine both components. We detect no decline in the average credit quality as reflected by hard information. In addition, the average internal risk rating (credit ranking assessed by loan officers) and interest rates did not change.

We do find, however, significant evidence of a shift in the use of soft information. In particular, although we do not observe a deterioration in the expected default rates (imputed using observable information), we find the ex-post default rates of the treated group increased significantly by $24 \%$. In other words, applications were approved if they looked good on paper (hard information), even though their soft information was not favorable. Both the expansion in the extensive and intensive margins contributed to the increase in the likelihood of default. Hence, ignoring critical soft information led to the lax credit approval.

Another important effect of the informational shift due to loan prospecting is the loss of predictive power of the Bank's imputed credit model. Whereas proxies of hard information (i.e., external credit scores) were good predictors of loans' ex-post performance for the control sample, they lost their predictive power for the treatment group. We observe a similar phenomenon when we estimate a more elaborated predictive default model and apply it to both the control and 
treatment groups. Why did ex-ante credit-quality variables lose their predictive power? We present evidence suggesting these variables became obsolete because they were "fitted" over a historical range of loan variables, such as amount. We show the imputed credit model still had good predictive power for loans with amounts that fell in the "normative" range. By contrast, the relation broke down for loans with amounts beyond this range. Because a credit model captures correlations between default and loan characteristics for a specific range, loans outside that range have different correlations the current model does not capture. This result is similar in spirit to Rajan, Seru, and Vig (2015), who present evidence that the default models used in the residential real estate industry lost predictive power with the move toward standardized underwriting.

In a final analysis, we explore the relation between loan-officer characteristics and origination outcomes. We document that applications handled by more tenured loan officers and by male loan officers were more likely to be approved. Also, conditional on approval, they were approved for significantly larger loan amounts. We attribute these results to fewer career concerns by tenured loan officers and by more competitive behavior by male loan officers. We also confirm that these correlations translate into actual compensation that these loan officers received: indeed, tenured loan officers and male loan officers receive larger compensation in the treatment group but not in the control group.

Overall, our results show the loan-prospecting pilot did not expand the Bank's reach to previously untapped pools of potential borrowers. Instead, loan approval expanded on both the extensive and intensive margins. The Bank relied more on hard information and less on soft information, which led to ignoring critical credit information and to higher default rates. The change in the information used in the approval process led also to a temporary breakdown in the imputed predictive credit model of the bank. 
This study contributes to several strands of the literature. The first strand relates to incentives and moral hazard in banks. In particular, Udell (1989), Berger and Udell (2002), Inderst (2008), and Heider and Inderst (2012) argue that when information asymmetry is present, loan officers may approve too many risky loans if their incentives are misaligned with those of their employer (the lender). An agency problem arises when the lending decision depends on information collected by the loan officer that the lender can neither observe nor verify (Petersen 2004). Although realigning incentives can theoretically mitigate the problem (e.g., by giving loan officers an equity stake in the transaction; see Sufi 2007), in practice, such realignment often does not occur. More broadly, the experiment we analyze is an example of how compensation for shortrun performance can lead to an increase in the risk exposure of banks (Bebchuck and Spamann 2009; Acharya, Cooley, Richardson, and Walter 2010; Acharya, Litov, and Sepe 2013; Tzioumis and Gee 2013).

This study also adds to the literature on information production in lending. Banks traditionally use both hard and soft information in approval decisions (Petersen 2004; Agarwal, Chomsisengphet, and Wang 2016). As physical distance between the bank and borrower increases, banks rely more on hard information (Petersen and Rajan 2002, Agarwal and Hauswald 2010).

Finally, our study relates to the literature on the financial crisis of 2008. In particular, we demonstrate the contribution of bonus-based loan-officer incentives to three phenomena that have been documented previously. First, researchers have noted that in the early 2000 s, the extensive margin of mortgage lending expanded; that is, new borrowers with lower credit quality entered the residential mortgage market (e.g., Mayer and Pence 2008). Second, several studies have found the leverage ratio of mortgage borrowers increased; that is, the intensive margin expanded (e.g., Demyanyk and Van Hemert 2011). Third, researchers have proposed that during boom times, 
lending criteria relax and loan officers ignore bad information, due to incentives or psychological biases (e.g., Acharya and Naqvi 2012; Gennaioli, Shleifer, and Vishny 2015; Thakor 2015). Finally, researchers have noted that in the wake of the recession, imputed default models based on historical defaults began to have poor predictive power going forward (Rajan, Seru, and Vig 2015).

\section{The Loan-Approval Process and the Loan-Prospecting Experiment}

\subsection{The Loan-Approval Process}

To better understand the impact of loan prospecting on the loan-approval process, one needs to understand the approval process itself. The Bank's branches offer retail services, and each branch has a small number of loan officers (typically one per branch). The loan-application process begins when a client — typically a small business owner —inquires about a potential business loan. During our sample period, the Bank offered a standard product: a five-year amortizing adjustablerate mortgage. In most cases, the loan officer encourages the client to submit an application for review on which the applicant states the requested amount, the collateral offered (either businessor self-owned collateral), ${ }^{1}$ and the purpose of the loan. The client also submits supporting information such as financial and tax information, and a list of assets owned.

The loan officer, who relies on both hard and soft information, then processes the application. The loan officer verifies the information provided by the borrower and gathers additional data to assess the borrower's creditworthiness and probability of repayment (e.g., the borrower's and business's credit rating with an external credit agency, appraisal of the collateral).

\footnotetext{
${ }^{1}$ Collateralized assets are typically accounts receivable (measured at their face value) or personal homes (measured using an automatic valuation model (AVM)). Loan officers have little control over these valuations. Agarwal, BenDavid, and Yao (2015) show that AVM produces less biased valuations than human appraisers.
} 
Then the loan officer conducts an in-depth interview with the client to understand why he or she is applying for the loan, as well as potential risks and prospects for the client's business. In some cases, the branch will invite the applicant to follow up on open questions, review discrepancies in credit-report information, discuss the prospects of the business, and so forth. Based on this information, the loan officer determines an internal risk-rating score, which summarizes his or her opinion of the potential borrower. ${ }^{2}$ Given the internal risk-rating score and additional information such as leverage and requested loan size, the computer system provides broad guidelines for the terms of the loan.

Each loan officer enjoys considerable autonomy in the assessment, approval, and pricing of loans but has to justify any deviation from bank-wide practices. The loan officer can also adjust the firm's internal score should the applicant deserve credit in the officer's opinion despite failing to meet certain credit-score requirements. These subjective score revisions represent the softinformation component of the Bank's internal credit assessment (see Agarwal and Hauswald 2011).

The local branches' credit committees, which are composed of the branch manager ${ }^{3}$ and the loan officer(s), ${ }^{4}$ make the credit decisions. They sketch the terms of the loan according to the Bank's lending guidelines and restrictions and can tailor those terms (including pricing) to the specific circumstances of the application (the Bank's risk-management staff closely monitor local overrides). Upon approval by the credit committee, the loan officer prepares an offer letter for the

\footnotetext{
${ }^{2}$ The Bank's lending process resembles that described in Petersen (2004), Berger, Miller, Petersen, Rajan, and Stein (2005), and Agarwal and Hauswald (2010). The Bank makes a limited attempt to code soft information, thereby transforming it into hard information.

${ }^{3}$ The branch managers' career prospects and remuneration are not tied to the compensation of loan officers but rather depend on the success of their credit decisions.

${ }^{4}$ Liberti and Mian (2009) find that greater hierarchical distance between the loan officers and the credit committee leads to greater reliance on hard information. The hierarchy did not change during the pilot experiment explored here.
} 
client with the details of the loan. Unlike residential loans, for which the lender approves or rejects the requested amount, commercial loans can be approved with an amount smaller or larger than that requested, subject to additional collateral.

Once an offer letter is received, the client may accept the loan, negotiate the terms, or withdraw the application. In 2004, the Bank approved 43\% of loan applications and rejected the rest. Of the $43 \%$, only $31 \%$ were originated, because $12 \%$ were withdrawn by applicants. All originated small business loans were kept on the Bank's balance sheet; none were sold or securitized. The entire lending process, including the credit decision, typically takes several weeks from the initial loan interview.

The loan officer does not have monitoring responsibilities over the loan. During the life of the loan, the risk-management department monitors the loan. On the anniversary of the loan's origination, the borrower meets with the loan officer to discuss the business's prospects and the potential need for additional financing.

\subsection{The Loan-Prospecting Pilot}

In 2004, the management of the New England division of a large U.S. commercial bank, ${ }^{5}$ motivated by competitive pressure from other lenders, decided to explore a set of incentives for small business loan officers to increase loan-prospecting efforts (consistent with the "bonus culture" model of Bénabou and Tirole 2016). Other lenders in the area had initiated performancebased compensation, and the management thought introducing such a payment structure would

\footnotetext{
${ }^{5}$ During the sample period, this lender ranked among the top five commercial banks and savings institutions, according to the Federal Deposit Insurance Corporation. All loan applications fall under the definition of small- and mediumsized enterprise lending in the Basel I Accord; thus, the total obligation of the applying firms is less than \$1 million and their sales are below $\$ 10$ million.
} 
improve the profitability of the unit. The program altered the compensation scheme from a fixed salary to a commission-based system. Under the proposed program, loan officers would receive a lower fixed salary ( $80 \%$ of their original salary) and a bonus that increased with the originated volume and origination efficiency. The Bank intended to implement the commission-based scheme for the entire portfolio of loan officers in stages to allow for evaluation of the effects of the new system. The pilot program was announced around June 2004.

The bonus system worked as follows. The loan officers were given a performanceevaluation formula. The performance metric was based on three components: originated dollar amount (50\% weight), number of loans (25\% weight), and the application decision time $(25 \%$ weight). Loan officers gained points on large loans, high origination volume, and quick decision turnaround. This three-pronged compensation structure forced the loan officer to generate loan volume efficiently and put more focus on larger loans. The incentive plan came with a quality assessment. For loan officers to be eligible to participate in the incentive program, their total of unsatisfactory underwriting could not exceed $5 \%$ of total approvals, assessed in a post-approval review process.

In the first stage, beginning in January 2005, the new scheme was put into action in a subset of branches that administered their human resources through one of the Bank's legacy databases. The Bank had evolved through several mergers and acquisitions, the most recent of which took place in mid-2001. Since then, the Bank had maintained two legacy computer systems that were used in administering human resources and compensation information. The incentive pilot, therefore, was implemented in one computer system (of the acquiring bank) and applied to all loan officers who were connected to that system. The remaining loan officers continued with their old compensation structure. Loan officers were not allowed to switch between the two systems. We 
call the group of branches that did not change their compensation structure Group A, and the group that experienced the compensation modification Group B.

The assignment of loan officers to each of the databases was quasi-random in the sense that it was unrelated to past performance or the prospects of loans or loan officers. Hence, the portfolio of loan applications the two groups of loan officers received have identical expected default rates, geographic focus, portfolio-management practices, and loss outcomes prior to the modification of the compensation structure. We formally test this proposition in section 3.3.

In such an experiment, loan officers might behave strategically. For example, they could approve bad loans so that management will retract the bonus-based compensation scheme. Although this behavior is theoretically possible, we doubt our results stem from such behavior. First, treated loan officers were located in different branches across different localities, and therefore are not likely to have colluded. Second, during informal conversations with loan officers and management, loan officers seemed enthusiastic about the new bonus system because it moved them closer to the compensation scheme that was prevalent in many of the competing banks. In section 3.4, we discuss additional potential Hawthorne effects.

The complete implementation of the commission-based scheme was supposed to take place in 2006; however, the program was discontinued prematurely. The risk-management division was monitoring this pilot on a monthly basis. At the beginning of 2006, the division advised the management that default rates were higher than expected and it therefore recommended abolishing the incentive program. The Bank's management decided to roll back the compensation structure to a fixed salary for all loan officers, as in the pre-2005 period. 


\section{Data and Identification}

Our data set contains all loan applications submitted to the New England division of the Bank in 2004 and 2005. Loan officer-years that were compensated with a fixed salary are defined as the control group. This group includes loan officer-years with compensation that did not change between 2004 and 2005 (Group A), as well as loan officer-months in 2004 from the group whose pay was altered in 2005 (Group B). The treatment group consists of loan officer-years in Group B in 2005 , that is, loan officer-years with pay in 2005 that was based on the volume originated. Unfortunately, we do not have access to loan applications made following the pilot in 2006.

\subsection{Empirical Identification}

In our empirical setting, the change in the scope of activities and compensation structure applied to only one group of loan officers, whereas the other group continued to operate as before and to be compensated at a fixed salary. The fact that the change occurred in one half of the population allows us to identify the effect of compensation using a difference-in-differences (diffin-diffs) approach. In this method, one uses time fixed effects to control for any temporal systematic shocks and loan-officer fixed effects to control for loan-officer average effects. ${ }^{6}$ Then the interaction between the treatment time (the 2005 dummy in our case) and the treatment group dummy (the group of loan officers who received incentive pay in 2005) captures the direct effect of the treatment (called the "loan-prospecting" dummy in our analysis).

For the effect of the scope of activities to be properly identified based on the diff-in-diffs setting, we need to ensure no confounding factors are present in the research design. In the current

\footnotetext{
${ }^{6}$ Given that we have loan-officer fixed effects and that borrowers are typically from the county where the branch is located, we do not include additional geographic fixed effects.
} 
study, we are concerned with two issues. The first is the possibility that the assignment to treatment and control groups was not random. Perhaps the group that was assigned to the treatment was different from the untreated group in some ways. Our conversations with the team responsible for the program's implementation confirmed the only active consideration in choosing the group to be treated was the ease with which the new scheme could be implemented in the computer system. Furthermore, we use the pre-experiment period (2004) to compare a host of variables related to both applications and credit decisions in the two groups. Our results show no significant difference in any of the variables we explore. The detailed analysis is described in section 3.3.

Another concern is that the emphasis on prospecting is confounded with additional changes to the lending process. Specifically, the expansion in the scope of the loan-officer role could be tied to a change in the underwriting model; for example, instead of the Bank holding the loans on its balance sheet, it may decide to start securitizing them. Such action might encourage loan officers to approve loans of lower credit quality (see Keys, Mukherjee, Seru, and Vig 2010). We discussed this possibility in depth with the managers of the program and were assured no additional structural changes in the lending process occurred in parallel with the implementation of the pilot program. A different form of this concern relates to the expected default rate. The Bank's management might have decided to lower the bar and thus accept applications with higher expected default rates. We test for this possibility in Table 4 (see section 5). Our results show the imputed expected default remained unchanged.

To summarize, we conclude that the diff-in-diffs identification strategy is appropriate for studying the effects of loan prospecting on the behavior of loan officers. Our identification is particularly strong because we control for loan-officer fixed effects, meaning the effects we identify are within-loan-officer effects. 


\subsection{Summary Statistics}

We begin our analysis by examining the summary statistics. Because of the large effects and the diff-in-diffs research design, many of the effects reported in the paper can be observed directly through the summary statistics. We split the data into a two-by-two matrix: 2004 versus 2005 and Group A versus Group B. The treatment group consists of loan officers from Group B in 2005. The control group consists of loan officers from Group A in 2004 and 2005, as well as loan officers from Group B in 2004.

The summary statistics for loan applications and originated loans are presented separately. In Table 1, Panel A, we show summary statistics for loan applications (all variables are explained in Appendix A). Requested loan amounts are approximately $\$ 445,000$. About $26 \%$ of the applicants propose using personal collateral (typically personal residence). Applicants are, on average, of high credit quality, with an average business Experian credit score of around 198 (out of a range of 100 to 250) and a personal Experian credit score around 728 (out of a range of 400 to 850 ). The average internal risk rating (determined by loan officers) is 5.8 (on a 1-10 range, where $10=$ very high risk).

The summary statistics in Table 1, Panels A and B, reveal sharp differences between the control and treatment groups in regard to approved and originated loans. First, the approval rate is $44 \%-51 \%$ for the control group but is $59 \%$ for the treatment group (Panel A). Second, the originated loan amount is $20 \%$ higher for the treatment group. Third, the leverage of the loans originated by treated loan officers (i.e., originated LTV) is substantially higher than that of those originated by the control group: $77 \%$ versus $75 \%$. Fourth, even though the borrowers' average credit score is higher for the treated group, the default rate - measured as $90+$ days past due within 
12 months - is materially higher for the treatment groups (5.2 percentage points vs. 4.2 percentage points). In the following subsections, we investigate these patterns in a diff-in-diffs setting.

Table 1, Panel C, presents summary statistics at the loan officer-month level for items in the regressions that use aggregate data (Table 3, Panel A, and Table 2, Panel A).

\subsection{Validating the Diff-in-Diffs Design}

The assignment of loan officers to treatment and control in 2005 was based on their association with the legacy or new human resources system. To draw conclusions from the experiment, we need to verify that the assignment of loan officers was not associated with the quality of the applications pretreatment or with the decisions loan officers made pretreatment.

We compare the characteristics of loan applications and originated loans of the control and treatment groups in 2004, prior to the initiation of the incentive program. Appendix B, Panel A, compares the control group and the to-be-treated group on several dimensions: the requested loan size, requested LTV, personal collateral indicator, Experian business credit score, Experian personal credit score, internal risk rating, time spent on applications, and withdrawal rate of approved applications. The panel shows the conditional means of these variables are statistically indistinguishable between the two groups. Panel B of Appendix B displays the results of a similar test for the subset of originated loans, instead of applications, in 2004. The difference between requested and originated logged loan sizes as well as between requested and originated LTV, interest rate, ${ }^{7}$ Experian business credit score, Experian personal credit score, and internal risk

\footnotetext{
${ }^{7}$ All loans are adjustable-rate loans. This fact should not be a concern, because all regressions include month fixed effects.
} 
rating are similar across groups. We intentionally omit loan-officer fixed effects from the regressions; when we add these effects, the variables of interest remain statistically insignificant.

Overall, these results show no observable difference between the control and treatment groups in 2004; therefore, we feel confident attributing the effects in the treated group in 2005 to loan prospecting rather than to differences between the groups.

\subsection{Potential Hawthorne Effects}

The loan officers who participated in the pilot knew they were observed. This fact could lead to potential Hawthorne effects (“observer effects"): participants reacting in a particular way because they are being observed. Two effects are possible. First, the actions of loan officers may have been exaggerated because the pilot was salient and new. The loan officers' reactions may have decayed over time, and thus our results are only an upper bound of the true results of the experiment. To assess whether indeed there is a change in the magnitude of the effect over time, we examine Figures 1 and 2. Figure 1 shows the average of the residual likelihood of approving loans, by month. ${ }^{8}$ Figure 2 presents the average loan size, by month. Both figures show no decay or trend in the magnitude of the effects during the first 12 months after the pilot was implemented.

The second potential effect is that loan officers could have behaved strategically to sway the management to reach conclusions in one direction or another. To assess whether our results are the effect of such behavior, we analyze the potential response of loan officers to the pilot. We assume the objective of loan officers was to minimize effort and maximize personal earnings. To do so, they would have milked the existing pool of applications in a way that (1) satisfied the

\footnotetext{
${ }^{8}$ See section 5 for a complete description of the procedure generating this figure.
} 
Bank's credit criteria and (2) did not require much additional work. If indeed loan officers behaved strategically, we can envision two potential cases, which lead to predictable patterns.

In the first case, loan officers may have liked the new compensation scheme and therefore acted strategically so that the pilot would succeed and the program would be approved. In this case, we would expect the loan officers to exert effort to bring new business to the bank (i.e., seek new applications). Also, they would have been diligent in the approval process, so that quality would not decline.

In the second case, loan officers did not like the new compensation scheme and acted strategically so that the pilot would fail. In this case, the loan officers would have acted to show the incentives did not work and that loan volume did not increase. Thus, the treated group would have continued to act as before.

Now, let us contrast these predictions with what we observe in the data. First, we observe no significant change in the behavior of the control group. Second, the behavior of the treated group appears to be consistent with a "minimum effort and maximum compensation" strategy; that is, loan officers did not seek new applications and the quality of the approved applications declined (inconsistent with the first case above). Also, their actions did lead to a significant increase in loan volume (inconsistent with the second case above).

Thus, our findings seem to be inconsistent with loan officers behaving in a reasonably strategic manner. We observe that compensation levels increased with little evidence of additional effort by loan officers. Specifically, we do not find evidence that the size of the application pool increased, that is, no application sourcing from previously untapped pools. Loan officers increased loan volume by using the easiest-to-execute methods: (1) ignoring negative soft information, and (2) conditional on approval, approving larger loans. 


\section{$4 \quad$ Direct Effects of Loan Prospecting}

We begin the analysis by diagnosing the first-order effects of loan prospecting. In particular, we are interested in how the program affected the flow of applications, extensive margin (approval rate), internal margin (loan size), and turnaround time. In all these dimensions, loan officers could have an effect given their expanded job description and pecuniary incentives. Also, the Bank's management is likely to use these dimensions to measure the program's success.

\subsection{Flow of Applications}

The objective of the pilot was to incentivize loan officers to seek new business; hence, they might have improved the quantity or quality of the application flow. Loan officers could have made such improvements in several ways. For example, they could have convinced the Bank's customers to apply for loans. They could have attracted loan applicants from other banks, for example, by raising awareness about the Bank's products and the quality of service. Finally, they could have improved the quality of the application flow by discouraging weak potential applicants from submitting applications (to save time down the line) and by encouraging strong but hesitant potential applicants to apply.

We perform three tests that explore whether the loan-prospecting experiment had an effect on the flow of applications. First, we test for a difference in the quantity of applications. In Table 2, Panel A, we analyze whether the application volume is statistically indistinguishable between the treatment and control groups. For each loan officer-month, we calculate the average requested loan amount across applications and count the number of applications. We regress the logged amount on an indicator of whether the loan officer is prospecting for loans. The results show that 
although the coefficients are positive for the average requested loan amount (an increase of up to $1.9 \%$ ) and the number of applications (an increase of up to $0.7 \%$ ), the effects are economically and statistically insignificant.

Second, we examine whether the quality of the applications is higher for the treatment group. To do so, we regress loan characteristics (requested amount, requested LTV, personal collateral, credit scores, and internal risk rating) on the loan-prospecting dummy. The results, presented in Table 2, Panel B, show no statistically significant difference in the quality of the applications between the two groups.

Finally, we test whether treated loan officers attracted applications that were more likely to be approved. To do so, we use pre-experiment (2004) data to estimate a model of loan approval as a function of application characteristics. Then we predict the likelihood of approval for each application in 2005 and test whether the treated group has loans that are more likely to be approved. We present the results in Table 2, Panel C, which indicates no significant difference in the ex-ante likelihood of approval in the treatment group.

Overall, the findings in Table 2 indicate prospecting loan officers did not attract new applications to the Bank, nor did they improve the quality of the applications the Bank received.

\subsection{Effects on the Extensive Margin}

The Bank's goal in proposing the loan-prospecting pilot was to increase the originated volume and to compete more forcefully in the credit market. We examine the effects of the loanprospecting program on the extensive margin in Table 3, Panel A, columns (1) to (4). The examined unit is loan officer-month, the dependent variable is the logged number of loans in a 
month, per loan officer, and the variable of interest is the loan-prospecting dummy. The results show the number of loans approved and originated increased by about $31 \%$ in the post-period, when both calendar-month fixed effects and loan-officer fixed effects are included (columns (2) and (4)).

We also present this effect in a graphical form. Figure 1 plots the residuals from a regression of an application-approval dummy on controls and fixed effects for month, loan officers, and industry (see Appendix C). We estimate the regression model using the control groups in 2004 and 2005 only, and calculate the residuals for both the control and treatment groups for 2004 and 2005. The plot shows the observed characteristics do not explain the high approval rate in the treatment group and that the dramatic increase occurred immediately after the pilot began.

\subsection{Effects on the Intensive Margin}

Next, we examine the intensive margin (loan amounts). In Table 3, Panel A, columns (5) to (8), we regress the average logged loan size per loan officer-month on the loan-prospecting dummy. The regressions show that for both the approved and originated loans, loan amounts increased by about 15\% (columns (6) and (8)). In fact, approved loan amounts in the treatment group were often larger than the amounts applicants requested. Table 1, Panel B, shows that in the treatment group, $17.4 \%$ of the approved amounts are larger than the amount originally requested, compared with about $3.5 \%$ in the control group.

Figure 2 plots the average approved loan size over time. The chart shows the average loan size increased around the beginning of 2005 in the treatment group and remained constant 
throughout the year, supporting the idea that the change in loan size is a direct effect of loan prospecting.

\subsection{Additional Effects: Turnaround Time and Withdrawal Rate}

The Bank was also interested in shortening turnaround times to help improve the quality of service. To measure whether the program indeed improved turnaround times, we measure the time from application to decision for two samples: all applications and approved applications. The dependent variable is the time from the application date to the decision date, measured in months (or month fractions). The variable of interest is an indicator for whether the application was submitted to a treated loan officer. The independent variables include the following controls: Experian business score, Experian personal score, logged requested loan amount, an indicator for whether personal collateral was used, the requested LTV, and the requested LTV-squared.

The results of the analysis, presented in Table 3, Panel B, columns (1) to (4), show turnaround time indeed declined for the treated group in 2005. For all applications, the average turnaround times declined by about three days in the treated group (about 40 days in the control group; see Table 1, Panel A). The decline in turnaround time is similar for the group of approved applications.

We also explore the effect of loan prospecting on the rate of withdrawal of approved applications. In Table 3, Panel B, columns (5) and (6), we use the sample of approved applications and regress a withdrawal indicator on the treatment indicator and the usual controls. The results show the withdrawal rate declines by $6.8 \%$ (column (6)), relative to a rate of about $13 \%$ in the

control (Table 1, Panel A). This effect is potentially due to a combination of factors: a greater 
effort by loan officers to convince hesitant applicants to sign on the dotted line, improvement in processing efficiency, and more aggressive loan terms.

\section{$5 \quad$ Loan Prospecting and Information Processing}

The fact that the pool of applications did not change in a material fashion, and yet credit provision expanded on both the extensive and intensive margins, suggests the Bank changed its risk tolerance (potentially inadvertently). One likely channel for this effect is through the information used to approve loan applications. In general, two types of information drive loanapproval decisions: hard information (which is observable) and soft information (which is unobservable) (Petersen 2004). Loan prospecting might have caused a change in how the Bank processes the different types of information.

\subsection{Hard Information Used in Approving Applications}

In a first set of tests, we explore whether the observable characteristics of approved applications are different across the two groups. To do so, we compare observable characteristics between the treatment and control group in the post-period, including the variables of interest: Experian business score, Experian personal score, internal risk rating, and interest rate. In the empirical specification, we restrict the sample to approved applications only and regress the variables of interest on the loan-prospecting dummy, in addition to logged approved loan amount, a personal-collateral indicator, approved LTV, and approved LTV-squared.

The results in Table 4, Panel A, show that approved applications in the control and treatment groups have statistically indistinguishable credit characteristics. Furthermore, they were 
charged indistinguishable interest rates, conditional on observable risk characteristics. This finding means that, observationally, loans in the control and the treatment groups have similar characteristics.

Next, we examine the relative importance of hard information in the approval decisions of the treatment and control groups. In Table 4, Panel B, we regress the approval indicator for all applications on interactions of loan prospecting and credit scores-both external and internal. Columns (1) and (2) present the base regressions, showing the applications were about $8 \%$ more likely to be approved under the treatment. In columns (3) to (6), we interact the loan-prospecting dummy with both hard-information measures (Experian business and personal scores) and a softinformation measure (internal risk rating).

The results show the weight on hard information (i.e., external credit scores) is greater for the treatment group. Explicitly, the weight of external information is nearly double for the treatment group relative to the control group (column (6)). By contrast, the weight on soft information (proxied by internal risk rating) declines for the loan-prospecting group (recall that the internal risk rating has high values for applications with poor credit quality). The weight of the internal risk ratings in the treatment group is $67 \%$ lower than that of the control group $((0.016-$ $0.024)=-0.008$ in the treatment relative to -0.024 in the control). Given that the standard error on the coefficient of the internal risk rating is in the vicinity of 0.010 , this weight of soft information in the treatment group is not statistically different from zero.

We deepen the analysis and explore whether an imputed credit-default model based on observable characteristics would detect an increase in the risk the bank takes. First, we investigate whether the imputed ex-ante credit quality for approved applications is the same in the treatment and control groups. We compute the imputed ex-ante credit quality as the likelihood of default 
based on a predictive regression of actual default on observable characteristics using 2004 data. In this regression, we predict default using the following characteristics: logged requested amount, a dummy for personal collateral, Experian business score, Experian personal score, requested LTV, and requested LTV-squared. In addition, we control for loan-officer and industry fixed effects. Next, we use the default predictions (based on the 2004 data) in the 2005 segment of the data and compare the predicted default probability of applications that were approved in the treatment and control groups in 2005 .

The results are presented in Table 4, Panel C. We first assess how the predicted default probability affects the likelihood of approval, loan size, and interest rate. In all regressions, the main effect of the predicted default probability is statistically significant and with the right sign: applications with a higher predicted default probability are less likely to be approved, their loan size is smaller (if approved), and their interest rate is higher (if approved). Column (1) shows the predicted default probability has the same impact on the likelihood of approval in the treatment and in the control groups. By contrast, columns (2) and (3) present evidence that, conditional on approval, the bank approved larger loan sizes to riskier borrowers, but also charged them higher interest rates.

Overall, these results indicate hard information became more important in the loanapproval process. Furthermore, we find little evidence that the imputed ex-ante credit quality of approved applications changed. Yet the loans originated under the treatment group have more aggressive terms. 


\subsection{Downplaying Soft Information}

Soft information is by definition unobservable; however, we can study its role in the approval process by exploring the default rate and its drivers. In particular, we know hard information became a prominent factor in approving applications and that observable quality of approved applications did not deteriorate. Hence, no change occurs in soft information, we expect the ex-post default rate to stay the same. However, if the ex-post default rate increases, we can conclude soft information that was critical in screening out bad applications is no longer used.

In a first pass, we explore whether the loans treated loan officers originated defaulted more frequently than those the control group originated. We measure loan performance as the default rate, defined as a delinquency of 90 days or more within one year of loan origination. The default rate in the control group is 4.2 percentage points in 2004-2005. In the treated group in 2005, it is higher: 5.2 percentage points (Table 1, Panel B). To test whether the univariate difference is statistically significant, we regress a default indicator on the loan-prospecting dummy in addition to loan-officer, industry, and month fixed effects. The results in Table 5, columns (1) and (2), show the default rate of the treated group is 1.2 percentage points higher (a $27.9 \%$ relative increase compared with the base default rate of $4.3 \%$ for the control group in 2005). In columns (3) and (4), we also control for the interest rates charged to the loans. This control should capture the Bank's imputed ex-ante risk. The coefficient on the loan-prospecting dummy remains virtually unchanged with this additional control, suggesting the increase in the default rate is not priced in the originated loans. Relative to the base default rate, the default rate is $27.9 \%$ higher for the treated group following the implementation of the loan-prospecting program. The interest rates charged to loans do not appear to capture the increased default risk. 
In the next step, we explore the determinants of the increase in default. We focus the analysis on variables that are correlated with the expansion in both the extensive and intensive margins, that is, new borrowers and aggressive lending terms.

We begin by exploring how new borrowers affect the default rate. We measure the new borrowers by estimating a residual from a regression of application approval on observable characteristics using the 2004 data (see Appendix C). A large residual from the application regression indicates a loan was not accepted based on the weights that were used to approve applications in the 2004. Table 6, column (1), shows the base regression with the usual controls and fixed effects: loan officer, industry, and month. As seen before, the treatment group's default rate is 1.3 percentage points higher. In column (2), we regress the default indicator on the residuals from the approval regression as well as on controls and fixed effects. The regression shows that although a high approval residual is associated with a higher default rate (the main effect of the loan-approval residual), the correlation is more than doubled for loans in the treated group. Hence, this result suggests new borrowers were partly responsible for the increase in default.

Next, we explore the role of the expansion in the intensive margin (larger loan amounts) on the increase in the default rate. In Table 6, column (3), the variable of interest is the interaction between the loan-prospecting group and an indicator for whether the loan amount was larger than what the borrower originally requested. The regression shows that loans with amounts greater than requested are 2.8 percentage points more likely to default under the control $(0.028$ is the coefficient on the main effect) and 4.6 percentage points more likely under the treatment $(=0.028+0.018)$. In column (4), we examine a variable that reflects abnormal LTV, computed as the residual from a regression of logged LTV on loan characteristics, which is based on a sample that includes only observations from the control group (see Appendix C). The regression in column (4) shows that 
loans with high residuals - that is, LTV is unusually high relative to the control group - are significantly more likely to default. The sensitivity of default to abnormal LTV is almost double that of the control sample.

Overall, these results show that under the pilot incentive program, the weight given to hard information in the approval decision increased, and soft information was discounted. The decline in the importance of soft information is asymmetrical; our results show negative soft information was ignored, leading to a higher default rate.

\section{Breakdown of the Credit Model}

We have shown the change in the scope of the loan officers' jobs and incentives significantly affected the origination process and the composition of the loan portfolio. Throughout the process, the Bank did not change its imputed approval criteria and credit model, but it did allow significantly larger loan amounts. Thus, an important question is how the Bank's predictive credit model fared. In other words, could the Bank have predicted the increase in default? A parallel could be drawn with the residential mortgage market during the early 2000s. There, old predictive credit models were applied to a new population (subprime borrowers) with more aggressive lending terms. Rajan, Seru, and Vig (2015) show the imputed predictive credit models that had been fitted to borrowers with prime credit lost their predictive power once they were applied to the subprime population.

The Bank's old credit model may have become obsolete due to a combination of two factors. First, as shown in section 5.1, the Bank's approval process began to rely more heavily on hard information. The combination of both types of information may have previously provided a 
good screen for borrowers, whereas relying primarily on hard information may have missed crucial details about applicants. Second, loan terms under the treatment group became significantly more aggressive. The sensitivity of performance to factors such as loan amounts and leverage might not be linear. Because the Bank was using a credit model that was fit on data with a certain range of amounts and leverages, the model may not have been applicable to loans with more aggressive terms.

To test the proposition that the Bank's predictive model became defunct, and to explore the reasons why, we conduct three tests. We have seen the Bank began to rely more heavily on hard information in the approval decision. The first test (Table 7, Panel A), therefore, examines how well observable information predicts ex-post default in the treatment versus the control groups. The table shows the different types of information (Experian business and personal information, as well as the internal risk rating) predict default for the entire sample. However, for the treatment, these variables lose their predictive ability.

The second test offers a more elaborated specification of a default predictor. As in Table 4, we use the predicted default (based on the 2004 data) to explain ex-post default of loans originated in 2005. For each originated loan in 2005, we compute the predicted default likelihood. We regress the actual default dummy on the predicted default variable as well as on the internal risk rating and interest rate. Table 7, Panel B, column (1), includes only the control sample in 2005. It shows that for this sample, all three variables explain actual default well; in particular, the predicted default predicts current ex-post default. The converse happens when we examine the treatment sample in 2005 (column (2)). For this sample, we find no relation between actual default and predicted default. Furthermore, loan officers' opinions (internal risk raking) are unrelated to actual default. Finally, the sensitivity of actual default to interest rates is about half the magnitude 
of that in the control sample. Column (3) presents these effects in a combined sample of the control and treatment groups in 2005 .

In a final analysis, we explore why the Bank's imputed predictive model stopped working. Our hypothesis is that the fitted model is doing a good job for originated loans that are similar to the loans in the sample in which it was estimated. However, we expect the fitted model to have poor predictive power for loans with non-normative terms. In Table 7, Panel C, we repeat the regressions of actual default on the predicted default probability. We split the data in two ways, both of which attempt to approximate the aggressiveness of loan terms. The first split is by whether loan officers approved loans larger than the amounts requested by applicants. ${ }^{9}$ Column (1) shows the subset of loans equal to or below the original requested amount. The regression indicates the interaction between the loan-prospecting dummy and the predicted default likelihood is statistically indistinguishable from zero. By contrast, for the subset of aggressive loans (column (2); loan amount is greater than requested), the interaction is negative and statistically significant. The magnitude of the coefficient is as large as that in the main effect, suggesting default is not predictable for this subset of loans based on the history of loans originated by the Bank in 2004 .

In the second test, we split the sample by abnormal loan amount. We estimate which loans have abnormal loan amounts, by regressing the logged loan amount on observable fundamentals (using 2004 data; see Appendix C). We use the residual as a measure of abnormal loan size. Then we categorize the 2005 originated loans as either less aggressive (column (3); residual is smaller than one standard deviation) or more aggressive (column (4); residual is greater than one standard deviation). Again, we repeat the regression specification from Panel B. For less aggressive loan

\footnotetext{
${ }^{9}$ As reported earlier, in the treatment sample, the fraction of originated loans with amounts greater than requested is $17 \%$, relative to a mere $3 \%$ in the control sample.
} 
terms (column (3)) the coefficient on the interaction of the loan-prospecting indicator and the predicted default likelihood is indistinguishable from zero, meaning the default of loans with less aggressive terms is predictable using 2004 data. Conversely, for more aggressive terms (column (4)), the performance of loans with aggressive amounts cannot be predicted using a predictor based on 2004 performance data.

Overall, our results show the Bank's imputed original credit model was fragile. Furthermore, the loans whose performance is the least predictable appear to be the loans whose amounts are outside the normative range of the Bank. Thus, changes in the approval process caused the imputed credit model to lose its predictive power.

\section{$7 \quad$ Loan-Officer Characteristics}

Our final analysis examines loan-officer characteristics and outcomes of the loanorigination process. We focus on two main characteristics: loan-officer tenure and gender. Loan officers who have been on the job longer have greater familiarity with the loan-origination process, as well as fewer career concerns. Hence, we expect loan officers who have been with the Bank for longer periods to exhibit higher approval rates than other loan officers following the loanprospecting experiment. We test this hypothesis in Table 8, Panel A. Using the sample of all applications, we regress the approval indicator on an interaction of the treatment dummy with a dummy for whether the loan officer has above-median tenure at the Bank. The results show that longer-tenured loan officers have approval rates that are 2.5 percentage points higher than those of their peers (compared with a 51.2\% approval rate in the control group in 2005). In column (6), we test the relation between logged loan amount and loan officers' tenure for the sample of 
approved loans. After controlling for application characteristics, we find that loans originated by tenured loan officers are 5 percentage points larger than those handled by less tenured peers.

We are also interested in the effect of loan officers' gender on loan outcome. Male loan officers may exhibit stronger competitive behavior (Gneezy, Niederle, and Rustichini 2003; Gneezy and Rustichini 2004) and may therefore be more willing to push loans more aggressively through the system. We test this hypothesis in column (3). Indeed, we find that applications handled by male loan officers in the treatment group are 2.0 percentage points more likely to be approved. Also, column (7) shows that applications handled by treated male loan officers have loan amounts that are 7.0 percentage points larger than loans originated by treated female loan officers.

Finally, we confirm that loan-officer characteristics indeed translate to larger salaries. We use a data set of loan officer-months to test this proposition. In Table 8, Panel B, we regress logged compensation on the treatment dummy interacted with loan-officer characteristics. The panel presents evidence that tenured loan officers and male loan officers earn higher salaries relative to their peers in the treatment group, but not in the control group.

Overall, our findings indicate tenure within the organization (potentially indicating lower career concerns) and gender may amplify the effects of loan prospecting.

\section{Conclusion}

In this paper, we present evidence that when a large commercial U.S. bank expanded the role of the loan officer from traditional loan screening to include a loan-prospecting component, the expansion resulted in dramatic changes to the origination process. In the corporate pilot 
program we study, the Bank provided incentives to loan officers to bring new business to the Bank ("loan prospecting"). The expected default of approved applications did not change, yet granted loan amounts rose. At a first glance, the pilot appears to have had some success: the Bank expanded its book of business through a greater number of approved loans at larger amounts. A caveat to this apparent success is the high default rate.

Our analysis shows the move to loan prospecting led to several striking changes in the loanorigination process. Despite the fact that loan officers did not bring new business to the Bank as expected, loan origination expanded on both the extensive margin (new borrowers) and the intensive margin (larger loan amounts). The bank relied more heavily on hard information in the approval process and discounted negative soft information. These policy changes led to material changes in the composition of borrower and loan characteristics. We show that due to these changes, the Bank's imputed credit model broke down and lost its predictive power.

These results highlight the importance of unintended consequences of changing business models. The management's effort to refocus loan officers to generate new business and compete better in the marketplace resulted in the dramatic loss of critical soft information, larger loans, and poor credit quality. In other words, the incentives to loan officers created a chain reaction that eventually led to a riskier loan portfolio. 


\section{References}

Acharya, Viral V., Thomas Cooley, Matthew Richardson, and Ingo Walter, 2010, Manufacturing Tail Risk: A Perspective on the Financial Crisis of 2007-2009, Foundations and Trends 4(4), 247-325.

Acharya, Viral V., Lubomir V. Litov, and Simone M. Sepe, 2013, Non-Executive Incentives and Bank Risk-Taking, Working Paper, New-York University.

Acharya, Viral, and Hassan Naqvi, 2012, The Seeds of a Crisis: A Theory of Bank Liquidity and Risk Taking Over the Business Cycle, Journal of Financial Economics 106(2), 349-366.

Agarwal, Sumit, Itzhak Ben-David, and Vincent Yao, 2015, Collateral Valuation and Institutional Pressures: Evidence from the Residential Real-Estate Market, Management Science, 61(9), 2220-2240.

Agarwal, Sumit, Souphala Chomsisengphet, and Qing Wang, 2016, Strategic Information Disclosure and Bank Lending, NUS Working Paper

Agarwal, Sumit, and Robert Hauswald, 2010, Distance and Private Information in Lending, Review of Financial Studies 23(7), 2757-2788.

Agarwal, Sumit, and Robert Hauswald, 2011, Authority and Information, Working Paper, Chicago Federal Reserve Bank.

Bebchuck, Lucian A., and Holger Spamann, 2009, Regulating Bankers' Pay, Georgetown Law Journal 98(2), 247-287.

Bénabou, Roland, and Jean Tirole, 2016, Bonus Culture: Competitive Pay, Screening, and Multitasking, Journal of Political Economy 124(2), 305-370.

Berger, Allen N., Nathan H. Miller, Mitchell A. Petersen, Raghuram G. Rajan, and Jeremy C. Stein, 2005, Does Function Follow Organizational Form? Evidence from the Lending Practices of Large and Small Banks, Journal of Financial Economics 76, 237-269.

Berger, Allen N., and Gregory F. Udell, 2002, Small Business Credit Availability and Relationship Lending: The Importance of Bank Organizational Structure, Economic Journal 112, 32-53.

Cole, Shawn, Martin Kanz, and Leora Klapper, 2015, Incentivizing Calculated Risk Taking: Evidence from an Experiment with Commercial Bank Loan Officers, Journal of Finance 70(2), 537-575.

Demyanyk, Yuliya, and Otto Van Hemert, 2011, Understanding the Subprime Mortgage Crisis, Review of Financial Studies 24(6), 1848-1880.

Gennaioli, Nicola, Andrei Shleifer, and Robert Vishny, 2015, Neglected Risks: The Psychology of Financial Crises, American Economic Review 105(5), 310-314.

Gneezy, Uri, Muriel Niederle, and Aldo Rustichini, 2003, Performance in Competitive Environments: Gender Differences, Quarterly Journal of Economics 118(3), 1049-1074.

Gneezy, Uri, and Aldo Rustichini, 2004, Gender and Competition at a Young Age, American Economic Review: Papers and Proceedings (May 2004), 377-381.

Heider, Florian, and Roman Inderst, 2012, Loan Prospecting, Review of Financial Studies 25(8), 23812415. 
Inderst, Roman, 2008, Loan Origination under Soft- and Hard-Information Lending, Working Paper, University of Frankfurt.

Keys, Benjamin J., Tanmoy Mukherjee, Amit Seru, and Vikrant Vig, 2010, Did Securitization Lead to Lax Screening? Evidence from Subprime Loans, Quarterly Journal of Economics 125(1), 307-362.

Liberti, Jose M., and Atif Mian, 2009, Estimating the Impact of Hierarchies on Information Use, Review of Financial Studies 22(10), 4057-4090.

Mayer, Christopher, and Kaen Pence, 2008, Subprime Mortgages: What, Where, and to Whom? Working Paper, Federal Reserve Board.

Petersen, Mitchell A., 2004, Information: Hard and Soft, Working Paper, Northwestern University.

Petersen, Mitchell A., and Raghuram G. Rajan, 2002, Does Distance Still Matter? The Information Revolution in Small Business Lending, Journal of Finance 57(6), 2533-2570.

Rajan, Uday, Amit Seru, and Vikrant Vig, 2015, The Failure of Models that Predict Failure: Distance, Incentives and Defaults, Journal of Financial Economics 115(2), 237-260.

Sufi, Amir, 2007, Information Asymmetry and Financing Arrangements: Evidence from Syndicated Loans, Journal of Finance 62(2), 629-668.

Thakor, Anjan, 2015, Lending Booms, Smart Bankers, and Financial Crises, American Economic Review 105(5), 305-309.

Tzioumis, Konstantinos, and Matthew Gee, 2013, Nonlinear Incentives and Mortgage Officers' Decisions, Journal of Financial Economics 107(2), 436-453.

Udell, Gregory F., 1989, Loan Quality, Commercial Loan Review and Loan Officer Contracting, Journal of Banking and Finance 13(3), 367-382.

U.S. Bureau of Labor Statistics, 2012, Loan Officers, in Occupational Outlook Handbook, 2012-13

Edition, U.S. Department of Labor, http://www.bls.gov/ooh/Business-and-Financial/Loan-officers.htm. 


\section{Appendix A. Variable Definitions}

Variable

Default within 12 months

Experian business score

Experian personal score

Internal risk rating

Loan originated

Loan-to-value (LTV)

Originated amount

Personal collateral

Requested amount
Residual from internal risk-rating regression

Residual from loan-originating regression

Residual from log(Originated amount) regression

from $\log$ (Originated amount) regression

\section{Description}

An indicator of whether the loan became delinquent (90 days or more past due) within 12 months of origination.

Applicant's Experian business credit score. Scores range from

100 to 250 . A higher score means higher credit quality.

Applicant's Experian personal credit score. Scores range from

400 to 850 . A higher score means higher credit quality.

The interest rate paid on the loan.

Applicant's risk rating as computed by the loan officer. Scores

range from 1 to 10 . Unlike Experian scores, a low internal risk

rating reflects higher credit quality.

An indicator of whether a loan application was originated by the

Bank.

An indicator of whether (1) the loan application was handled by

a loan officer who is part of Group B (loan prospecting treatment

in 2005) and (2) the year of the loan application is 2005.

The loan amount divided by the value of the collateral.

The dollar amount originated by the Bank.

An indicator variable as to whether the loan applicant proposes

collateralizing a personal asset $(=1)$ or a business asset $(=0)$.

The dollar amount requested by the loan applicant.

Residual from a regression of the internal risk-rating variable on loan characteristics (see Appendix C).

Residual from a regression of the loan-originated variable on loan characteristics (see Appendix C).

Residual from a regression of the $\log$ (originated amount) variable on loan characteristics (see Appendix C).

Residual from LTV regression Residual from a regression of the LTV variable on loan characteristics (see Appendix C).

Time spent Time interval between application submission and decision.

Measured in months.

Withdrawn

An indicator of whether a loan application was withdrawn before or after the Bank made a decision. 


\section{Appendix B. Comparing Groups A and B in 2004}

The table compares the characteristics of applications and originated loans of Groups A and B in 2004. Panel A tests whether loan applications received by Group A (control) and Group B (to be treated in 2005) are different in the pretreatment period (2004). Panel B does the same for originated loans. All regressions are ordinary least squares regressions. Variables are defined in Appendix A. Standard errors are clustered at the loan-officer level. Standard errors are reported in parentheses. $* * * * *$, and $*$ denote statistical significance at the $1 \%, 5 \%$, and $10 \%$ levels, respectively.

\section{Panel A: Loan Applications in Groups A and B in 2004}

\begin{tabular}{|c|c|c|c|c|c|c|c|c|c|}
\hline \multirow[t]{2}{*}{ Dependent variable } & e: $\log$ (Req'd amount) & $\begin{array}{l}\text { Personal } \\
\text { collateral }\end{array}$ & $\begin{array}{c}\text { Requested } \\
\text { LTV } \\
\end{array}$ & $\begin{array}{c}\text { Experian } \\
\text { business score } \\
\end{array}$ & $\begin{array}{c}\text { Experian } \\
\text { personal score } \\
\end{array}$ & $\begin{array}{c}\text { Internal } \\
\text { risk rating }\end{array}$ & $\begin{array}{l}\text { Time } \\
\text { spent }\end{array}$ & $\begin{array}{c}\text { Application } \\
\text { withdrawn }\end{array}$ & $\begin{array}{c}\begin{array}{c}\text { Loan officer } \\
\text { salary (\$k) }\end{array} \\
\end{array}$ \\
\hline & $(1)$ & $(2)$ & (3) & $\begin{array}{l}(4) \\
\end{array}$ & $(5)$ & $(6)$ & $(7)$ & $(8)$ & (9) \\
\hline \multirow[t]{2}{*}{ Group B (to be treated in 2005) $(0 / 1)$} & -0.035 & -0.041 & 0.001 & -3.169 & -4.176 & 0.004 & 0.001 & 0.003 & 0.343 \\
\hline & $(0.050)$ & $(0.125)$ & $(0.014)$ & $(3.298)$ & $(5.623)$ & $(0.007)$ & $(0.048)$ & $(0.009)$ & $(0.579)$ \\
\hline \multirow[t]{2}{*}{$\log ($ Requested amount $)$} & & & $0.036 * * *$ & -0.013 & -0.006 & 0.004 & 0.007 & 0.135 & 0.773 \\
\hline & & & $(0.011)$ & $(0.010)$ & $(0.014)$ & $(0.018)$ & $(0.026)$ & $(0.057)$ & $(0.818)$ \\
\hline \multirow[t]{2}{*}{ Personal collateral $(0 / 1)$} & 0.046 & 0.022 & -0.027 & 0.033 & 0.021 & -0.007 & -0.009 & $0.030^{*}$ & 0.260 \\
\hline & $(0.046)$ & $(0.075)$ & $(0.026)$ & $(0.022)$ & $(0.028)$ & $(0.041)$ & $(0.055)$ & $(0.015)$ & $(0.176)$ \\
\hline \multicolumn{2}{|l|}{ Requested LTV } & & $\begin{array}{c}0.018 * * * \\
(0.006)\end{array}$ & $\begin{array}{c}0.037 \\
(0.037)\end{array}$ & $\begin{array}{c}0.001 * * \\
(0.000)\end{array}$ & $\begin{array}{c}0.002 \\
(0.008)\end{array}$ & $\begin{array}{c}0.002 \\
(0.010)\end{array}$ & $\begin{array}{c}0.070^{* * * *} \\
(0.019)\end{array}$ & $\begin{array}{c}0.028 \\
(0.021)\end{array}$ \\
\hline Requested LTV ${ }^{2}$ & & & $\begin{array}{c}0.038^{* * *} \\
(0.005)\end{array}$ & $\begin{array}{c}-0.043 * * \\
(0.021)\end{array}$ & $\begin{array}{c}-0.004 * * * \\
(0.001)\end{array}$ & $\begin{array}{c}0.004 \\
(0.038)\end{array}$ & $\begin{array}{c}0.005 \\
(0.055)\end{array}$ & $\begin{array}{l}0.0407^{*} \\
(0.021)\end{array}$ & $\begin{array}{c}0.008 \\
(0.007)\end{array}$ \\
\hline Experian business score & $\begin{array}{c}0.028 * * * \\
(0.008)\end{array}$ & $\begin{array}{c}0.047 * * * \\
(0.008)\end{array}$ & $\begin{array}{c}-0.064 * * * \\
(0.015)\end{array}$ & & $\begin{array}{c}0.030 * * * \\
(0.008)\end{array}$ & $\begin{array}{c}-0.007^{* * *} \\
(0.003)\end{array}$ & $\begin{array}{l}-0.005 \\
(0.003)\end{array}$ & $\begin{array}{c}-0.141^{* * *} \\
(0.050)\end{array}$ & $\begin{array}{c}0.265 \\
(0.420)\end{array}$ \\
\hline Experian personal score & $\begin{array}{l}0.0368 \\
(0.058)\end{array}$ & $\begin{array}{c}0.057 * * * \\
(0.018)\end{array}$ & $\begin{array}{l}-0.020 \\
(0.034)\end{array}$ & $\begin{array}{l}0.029^{*} \\
(0.017)\end{array}$ & & $\begin{array}{c}-0.035^{* * *} \\
(0.004)\end{array}$ & $\begin{array}{c}-0.045^{* * *} \\
(0.004)\end{array}$ & $\begin{array}{l}-0.091^{*} \\
(0.048)\end{array}$ & $\begin{array}{c}0.182 \\
(0.136)\end{array}$ \\
\hline Loan officer fixed effects & No & No & No & No & No & No & No & No & No \\
\hline Industry fixed effects & Yes & Yes & Yes & Yes & Yes & Yes & Yes & Yes & No \\
\hline Month fixed effects & Yes & Yes & Yes & Yes & Yes & Yes & Yes & Yes & Yes \\
\hline Observations & 14,916 & 14,916 & 14,916 & 14,916 & 14,916 & 14,916 & 14,916 & 14,916 & 14,916 \\
\hline Adj. $\mathrm{R}^{2}$ & 0.05 & 0.07 & 0.19 & 0.11 & 0.10 & 0.73 & 0.20 & 0.07 & 0.06 \\
\hline
\end{tabular}




\section{Appendix B. Comparing Groups A and B in 2004 (Cont.)}

\section{Panel B: Originated Loans in Groups A and B in 2004}

\begin{tabular}{|c|c|c|c|c|c|c|c|}
\hline Dependent variable & $\begin{array}{r}\log (\text { Originated amount }) \\
:-\log (\text { Requested amount }) \\
\end{array}$ & $\begin{array}{l}\text { Personal } \\
\text { collateral } \\
\end{array}$ & $\begin{array}{c}\text { Originated LTV } \\
\text {-Requested LTV (\%) } \\
\end{array}$ & Interest rate & $\begin{array}{c}\begin{array}{c}\text { Experian } \\
\text { business score }\end{array} \\
\end{array}$ & $\begin{array}{c}\begin{array}{c}\text { Experian } \\
\text { personal score }\end{array} \\
\end{array}$ & $\begin{array}{c}\text { Internal } \\
\text { risk rating } \\
\end{array}$ \\
\hline & & (2) & (3) & (4) & & & (7) \\
\hline Group B (to be treated in 2005) $(0 / 1)$ & $\begin{array}{l}-0.020 \\
(0.050)\end{array}$ & $\begin{array}{c}0.325 \\
(0.568)\end{array}$ & $\begin{array}{l}-0.038 \\
(0.061)\end{array}$ & $\begin{array}{c}0.001 \\
(0.016)\end{array}$ & $\begin{array}{l}1.070 \\
(2.204)\end{array}$ & $\begin{array}{c}1.586 \\
(2.431)\end{array}$ & $\begin{array}{c}0.003 \\
(0.009)\end{array}$ \\
\hline $\log ($ Requested amount) & & $\begin{array}{c}0.481 \\
(0.439)\end{array}$ & & $\begin{array}{c}0.034 * * * \\
(0.010)\end{array}$ & $\begin{array}{l}-0.010 \\
(0.009)\end{array}$ & $\begin{array}{l}-0.006 \\
(0.012)\end{array}$ & $\begin{array}{c}0.003 \\
(0.015)\end{array}$ \\
\hline Personal collateral & $\begin{array}{c}0.053 \\
(0.045)\end{array}$ & & $\begin{array}{c}0.042 \\
(0.065)\end{array}$ & $\begin{array}{l}-0.023 \\
(0.021)\end{array}$ & $\begin{array}{c}0.032 \\
(0.021)\end{array}$ & $\begin{array}{c}0.018 \\
(0.019)\end{array}$ & $\begin{array}{l}-0.006 \\
(0.037)\end{array}$ \\
\hline Requested LTV & & $\begin{array}{c}0.024 \\
(0.021)\end{array}$ & & $\begin{array}{c}0.016 * * * \\
(0.005)\end{array}$ & $\begin{array}{c}0.033 \\
(0.035)\end{array}$ & $\begin{array}{l}0.001 * * \\
(0.000)\end{array}$ & $\begin{array}{c}0.002 \\
(0.007)\end{array}$ \\
\hline Requested $\mathrm{LTV}^{2}$ & & $\begin{array}{c}0.006 \\
(0.004)\end{array}$ & & $\begin{array}{c}0.037 * * * \\
(0.005)\end{array}$ & $\begin{array}{c}-0.035^{* * * *} \\
(0.022)\end{array}$ & $\begin{array}{c}-0.004 * * * \\
(0.001)\end{array}$ & $\begin{array}{c}0.004 \\
(0.032)\end{array}$ \\
\hline Experian business score & $\begin{array}{c}0.024 * * * \\
(0.008)\end{array}$ & $\begin{array}{c}0.198 \\
(0.242)\end{array}$ & $\begin{array}{c}0.034 * * * \\
(0.008)\end{array}$ & $\begin{array}{c}-0.055^{* * *} \\
(0.012)\end{array}$ & & $\begin{array}{c}0.024 * * * \\
(0.007)\end{array}$ & $\begin{array}{c}-0.006^{* * *} \\
(0.002)\end{array}$ \\
\hline Experian personal score & $\begin{array}{c}0.041 \\
(0.087)\end{array}$ & $\begin{array}{l}0.167 * \\
(0.089)\end{array}$ & $\begin{array}{l}0.037 * * * \\
(0.007)\end{array}$ & $\begin{array}{l}-0.018 \\
(0.029)\end{array}$ & $\begin{array}{l}0.022^{*} \\
(0.013)\end{array}$ & & $\begin{array}{c}-0.032 * * * \\
(0.004)\end{array}$ \\
\hline Loan officer fixed effects & No & No & No & No & No & No & No \\
\hline Industry fixed effects & Yes & Yes & Yes & Yes & Yes & Yes & Yes \\
\hline Month fixed effects & Yes & Yes & Yes & Yes & Yes & Yes & Yes \\
\hline Observations & 4,740 & 4,740 & 4,740 & 4,740 & 4,740 & 4,740 & 4,740 \\
\hline Adj. $\mathrm{R}^{2}$ & 0.07 & 0.05 & 0.11 & 0.21 & 0.12 & 0.10 & 0.69 \\
\hline
\end{tabular}




\section{Appendix C. Calculating Residuals}

The table presents analysis used to calculate abnormal application approval, as well as abnormal leverage and loan amount. The sample contains only applications (column (1)) and approved loans (columns (2) and (3)) from the control group: Group A in 2004 and 2005, and Group B in 2004. All regressions are ordinary least squares regressions. Variables are defined in Appendix A. Standard errors are clustered at the loan-officer level. Standard errors are reported in parentheses. $* * *, * *$, and $*$ denote statistical significance at the $1 \%, 5 \%$, and $10 \%$ levels, respectively.

\begin{tabular}{|c|c|c|c|}
\hline \multirow{3}{*}{$\begin{array}{l}\text { Sample: } \\
\text { Dependent variable: }\end{array}$} & \multirow{2}{*}{$\begin{array}{c}\text { Applications (Control only) } \\
\text { Loan approved }(0 / 1)\end{array}$} & \multicolumn{2}{|c|}{ Approved loans (Control only) } \\
\hline & & LTV & $\log$ (Loan amount) \\
\hline & $(1)$ & $(2)$ & (3) \\
\hline \multirow[t]{2}{*}{$\log ($ Requested amount $)$} & $-0.3007 * *$ & 0.0256 & -0.0164 \\
\hline & $(0.0700)$ & $(0.0224)$ & $(0.0122)$ \\
\hline \multirow[t]{2}{*}{ Personal collateral $(0 / 1)$} & $0.0215 * * *$ & $-0.0395 * * *$ & $0.0818 * *$ \\
\hline & $(0.0077)$ & $(0.0070)$ & $(0.0344)$ \\
\hline \multirow[t]{2}{*}{ Experian business score } & $-0.1397 * * *$ & $-0.0063 * * *$ & $0.0032 * * *$ \\
\hline & $(0.0481)$ & $(0.0004)$ & $(0.0008)$ \\
\hline \multirow[t]{2}{*}{ Experian personal score } & $-0.1295 * * *$ & $-0.0052 * * *$ & $0.0093 * * *$ \\
\hline & $(0.0391)$ & $(0.0012)$ & $(0.0003)$ \\
\hline \multirow[t]{2}{*}{ LTV (Requested) } & $0.0471 * * *$ & $-0.6075 * * *$ & $-0.8142 * * *$ \\
\hline & $(0.0139)$ & $(0.0838)$ & $(0.2224)$ \\
\hline \multirow[t]{2}{*}{ LTV $^{2}$ (Requested) } & $-0.0796 * * *$ & $-0.7031 * * *$ & $0.6948 * * *$ \\
\hline & $(0.0162)$ & $(0.0774)$ & $(0.1485)$ \\
\hline Loan officer fixed effects & Yes & Yes & Yes \\
\hline Industry fixed effects & Yes & Yes & Yes \\
\hline Month fixed effects & Yes & Yes & Yes \\
\hline Observations & 22,480 & 10,470 & 10,470 \\
\hline Adj. $\mathrm{R}^{2}$ & 0.17 & 0.14 & 0.10 \\
\hline
\end{tabular}




\section{Table 1. Summary Statistics}

The table presents summary statistics for the data used in the study. Panel A presents summary statistics for loan applications. Panel B presents summary statistics for the originated loans. Panel C presents summary statistics for data aggregated at the loan officer-month level. Variables are defined in Appendix A.

\section{Panel A: Loan Applications}

\begin{tabular}{|c|c|c|c|c|c|c|c|c|}
\hline \multirow{4}{*}{ \# Applications: } & \multicolumn{4}{|c|}{2004} & \multicolumn{4}{|c|}{2005} \\
\hline & \multirow{2}{*}{\multicolumn{2}{|c|}{$\frac{\text { Group A (Control) }}{6,920}$}} & \multirow{2}{*}{\multicolumn{2}{|c|}{$\begin{array}{c}\text { Group B (Control) } \\
7,996\end{array}$}} & \multirow{2}{*}{\multicolumn{2}{|c|}{$\begin{array}{c}\text { Group A (Control) } \\
7,564\end{array}$}} & \multirow{2}{*}{\multicolumn{2}{|c|}{$\frac{\text { Group B (Treatment) }}{7,788}$}} \\
\hline & & & & & & & & \\
\hline & Mean & St Dev & Mean & St Dev & Mean & St Dev & Mean & St Dev \\
\hline Requested amount (\$) & 455,240 & 336,805 & 426,480 & 378,698 & 454,141 & 369,635 & 444,137 & 381,829 \\
\hline Personal collateral $(0 / 1)$ & 0.255 & 0.436 & 0.261 & 0.439 & 0.280 & 0.449 & 0.239 & 0.427 \\
\hline Requested LTV (\%) & 61.283 & 43.001 & 65.301 & 44.029 & 65.161 & 46.873 & 63.049 & 43.483 \\
\hline Experian business score $(100-250)$ & 200.863 & 72.228 & 195.884 & 75.868 & 195.988 & 75.273 & 200.359 & 68.471 \\
\hline Experian personal score $(400-850)$ & 731.847 & 70.305 & 725.405 & 68.063 & 725.908 & 74.394 & 728.057 & 76.723 \\
\hline Internal risk rating $(1-10)$ & 5.819 & 1.734 & 5.813 & 1.537 & 5.940 & 1.313 & 5.958 & 1.470 \\
\hline Time spent (months) & 1.380 & 0.850 & 1.350 & 0.700 & 1.320 & 0.750 & 1.060 & 0.530 \\
\hline Application approved (0/1) & 0.449 & 0.497 & 0.436 & 0.496 & 0.512 & 0.500 & 0.592 & 0.491 \\
\hline Withdrawn after being approved $(0 / 1)$ & 0.132 & 0.338 & 0.118 & 0.322 & 0.150 & 0.357 & 0.119 & 0.324 \\
\hline
\end{tabular}

\section{Panel B: Originated Loans}

\begin{tabular}{|c|c|c|c|c|c|c|c|c|}
\hline \multirow{4}{*}{ \# Originated loans } & \multicolumn{4}{|c|}{2004} & \multicolumn{4}{|c|}{2005} \\
\hline & \multirow{2}{*}{\multicolumn{2}{|c|}{$\begin{array}{c}\text { Group A (Control) } \\
2,192\end{array}$}} & \multirow{2}{*}{\multicolumn{2}{|c|}{$\begin{array}{c}\text { Group B (Control) } \\
2,548\end{array}$}} & \multirow{2}{*}{\multicolumn{2}{|c|}{$\begin{array}{c}\text { Group A (Control) } \\
2,744\end{array}$}} & \multirow{2}{*}{\multicolumn{2}{|c|}{$\begin{array}{c}\text { Group B (Treatment) } \\
3,680 \\
\end{array}$}} \\
\hline & & & & & & & & \\
\hline & Mean & St Dev & Mean & St Dev & Mean & St Dev & Mean & St Dev \\
\hline Loan originated $(0 / 1)$ & 0.306 & 0.461 & 0.322 & 0.467 & 0.357 & 0.499 & 0.466 & 0.476 \\
\hline Requested amount (\$) & 302,074 & 305,891 & 302,966 & 301,933 & 303,082 & 306,939 & 302,224 & 317,073 \\
\hline Originated amount (\$) & 224,614 & 279,361 & 216,048 & 229,403 & 253,219 & 257,801 & 301,004 & 299,013 \\
\hline I(Amount approved $>$ Amount requested) & 0.035 & 0.025 & 0.032 & 0.028 & 0.032 & 0.027 & 0.174 & 0.073 \\
\hline Personal collateral (originated) $(0 / 1)$ & 0.270 & 0.409 & 0.280 & 0.403 & 0.300 & 0.420 & 0.250 & 0.404 \\
\hline Requested LTV (\%) & 79.060 & 20.930 & 78.440 & 19.280 & 79.030 & 17.040 & 78.520 & 18.400 \\
\hline Originated LTV $(\%)$ & 72.986 & 31.477 & 76.237 & 30.899 & 74.901 & 33.105 & 77.033 & 26.049 \\
\hline Experian business score $(100-250)$ & 184.870 & 68.946 & 186.115 & 78.924 & 185.500 & 93.091 & 196.095 & 87.015 \\
\hline Experian personal score $(400-850)$ & 716.692 & 87.439 & 718.897 & 88.580 & 719.537 & 98.245 & 725.765 & 66.510 \\
\hline Time spent (months) & 1.270 & 0.880 & 1.282 & 0.858 & 1.275 & 0.799 & 1.020 & 0.540 \\
\hline Internal risk rating (1-10) & 5.230 & 1.840 & 5.380 & 1.520 & 5.440 & 1.300 & 4.930 & 1.530 \\
\hline Interest rate $(\%)$ & 9.910 & 5.020 & 9.850 & 4.890 & 9.580 & 4.880 & 9.650 & 4.930 \\
\hline \# Defaults & 91 & & 107 & & 119 & & 192 & \\
\hline Defaulted within 12 months $(0 / 1)$ & 0.042 & 0.199 & 0.042 & 0.201 & 0.043 & 0.204 & 0.052 & 0.222 \\
\hline $\log ($ Originated amount $)-\log ($ Requested amount $)$ & -0.129 & -0.039 & -0.146 & -0.117 & -0.077 & -0.075 & 0.014 & 0.104 \\
\hline Originated LTV-Requested LTV & -0.060 & 0.104 & -0.022 & 0.116 & -0.041 & 0.158 & 0.007 & 0.080 \\
\hline Residual from leverage regression & 0.003 & 0.034 & 0.003 & 0.033 & 0.004 & 0.032 & 0.007 & 0.032 \\
\hline Residual from loan size regression & 0.004 & 0.038 & 0.003 & 0.040 & 0.004 & 0.042 & 0.071 & 0.039 \\
\hline
\end{tabular}


Table 1. Summary Statistics (Cont.)

\section{Panel C: Loan Officer-Month Data}

\begin{tabular}{|c|c|c|c|c|c|c|c|c|}
\hline & \multicolumn{4}{|c|}{2004} & \multicolumn{4}{|c|}{2005} \\
\hline & \multirow{2}{*}{\multicolumn{2}{|c|}{$\begin{array}{c}\text { Group A (Control) } \\
68\end{array}$}} & \multirow{2}{*}{\multicolumn{2}{|c|}{$\begin{array}{c}\text { Group B (Control) } \\
65\end{array}$}} & \multirow{2}{*}{\multicolumn{2}{|c|}{$\frac{\text { Group A (Control) }}{65}$}} & \multirow{2}{*}{\multicolumn{2}{|c|}{$\begin{array}{c}\text { Group B (Treatment) } \\
65\end{array}$}} \\
\hline \# Loan officers: & & & & & & & & \\
\hline & Mean & St Dev & Mean & St Dev & Mean & St Dev & Mean & St Dev \\
\hline $\log ($ Application avg amount (\$k)) & 5.582 & 5.336 & 5.382 & 5.352 & 5.587 & 5.349 & 5.399 & 5.534 \\
\hline $\log ($ Approved avg amount $(\$ \mathrm{k}))$ & 5.293 & 5.562 & 5.296 & 5.485 & 5.290 & 5.433 & 5.525 & 5.661 \\
\hline $\log ($ Originated avg amount $(\$ \mathrm{k}))$ & 5.281 & 5.394 & 5.299 & 5.307 & 5.294 & 5.374 & 5.551 & 5.446 \\
\hline $\log (\#$ Applications $)$ & 3.794 & 1.885 & 3.795 & 1.884 & 3.799 & 1.865 & 3.812 & 1.842 \\
\hline $\log (\#$ Approved loans) & 3.378 & 1.858 & 3.399 & 1.878 & 3.381 & 1.840 & 3.705 & 1.819 \\
\hline $\log (\#$ Originated loans $)$ & 3.373 & 1.861 & 3.396 & 1.861 & 3.391 & 1.834 & 3.816 & 1.840 \\
\hline Salary $(\$)$ & 43,292 & 32,941 & 43,023 & 32,114 & 43,139 & 32,327 & 47,305 & 32,672 \\
\hline $\log ($ Salary $(\$))$ & 4.567 & 4.555 & 4.583 & 4.544 & 4.608 & 4.601 & 4.660 & 4.521 \\
\hline Tenure (years) & 3.1 & 2.6 & 3.1 & 2.6 & 3.0 & 2.6 & 3.1 & 2.6 \\
\hline Male $(\%)$ & 62.9 & & 68.0 & & 64.5 & & 66.9 & \\
\hline
\end{tabular}

$\mathrm{N}($ loan officer-month $)=3,192$ 


\section{Table 2. Volume and Quality of Applications}

The table presents an analysis of the loan-application volume and characteristics. Panel A uses a sample at the loan officer-month level and explores whether the dollar volume and the number of applications are different for applications made to loan officers who engaged in loan prospecting. Panel B tests whether the characteristics of loan applications are different for applications made to loan officers who engage in loan prospecting. Panel $\mathrm{C}$ tests whether loan applications received by the loan-prospecting group were more likely to be approved based on characteristics. All regressions are ordinary least squares regressions. Variables are defined in Appendix A. In Panel A, standard errors are clustered at the month level. In Panels B and C, standard errors are clustered at the loan-officer level. Standard errors are reported in parentheses. $* * *, * *$, and $*$ denote statistical significance at the $1 \%, 5 \%$, and $10 \%$ levels, respectively.

\section{Panel A: Loan-Application Volume in Treated and Control Groups}

\begin{tabular}{|c|c|c|c|c|}
\hline \multirow{3}{*}{$\begin{array}{l}\text { Dependent variable: } \\
\text { Denoted in: }\end{array}$} & \multicolumn{4}{|c|}{ All applications (loan officer-month) } \\
\hline & \multicolumn{2}{|c|}{$\log ($ Avg requested amount $(\$))$} & \multicolumn{2}{|c|}{$\log$ (\# Applications) } \\
\hline & $(1)$ & $(2)$ & (3) & (4) \\
\hline Loan prospecting $(0 / 1)$ & $\begin{array}{c}0.019 \\
(0.029)\end{array}$ & $\begin{array}{c}0.013 \\
(0.030)\end{array}$ & $\begin{array}{c}0.001 \\
(0.013)\end{array}$ & $\begin{array}{c}0.007 \\
(0.025)\end{array}$ \\
\hline Loan officer fixed effects & No & No & No & No \\
\hline Month fixed effects & No & Yes & No & Yes \\
\hline Observations & 3,192 & 3,192 & 3,192 & 3,192 \\
\hline Adj. $\mathrm{R}^{2}$ & 0.07 & 0.13 & 0.06 & 0.08 \\
\hline
\end{tabular}

Panel B: Characteristics of Loan Applications

\begin{tabular}{|c|c|c|c|c|c|c|}
\hline Dependent variable: & $\frac{\log (\text { Requested amount })}{(1)}$ & $\frac{\text { Requested LTV }}{(2)}$ & $\begin{array}{c}\begin{array}{c}\text { Personal } \\
\text { collateral }\end{array} \\
(3)\end{array}$ & $\begin{array}{c}\begin{array}{c}\text { Experian } \\
\text { business score }\end{array} \\
(4)\end{array}$ & $\begin{array}{c}\begin{array}{c}\text { Experian } \\
\text { personal score }\end{array} \\
(5)\end{array}$ & $\begin{array}{c}\begin{array}{c}\text { Internal } \\
\text { risk rating }\end{array} \\
(6)\end{array}$ \\
\hline Loan prospecting $(0 / 1)$ & $\begin{array}{c}0.016 \\
(0.064)\end{array}$ & $\begin{array}{c}0.026 \\
(0.183)\end{array}$ & $\begin{array}{c}0.014 \\
(0.056)\end{array}$ & $\begin{array}{c}7.146 \\
(5.871)\end{array}$ & $\begin{array}{c}3.976 \\
(5.068)\end{array}$ & $\begin{array}{c}0.043 \\
(0.138)\end{array}$ \\
\hline Loan officer fixed effects & No & No & No & No & No & No \\
\hline Industry fixed effects & Yes & Yes & Yes & Yes & Yes & Yes \\
\hline Month fixed effects & Yes & Yes & Yes & Yes & Yes & Yes \\
\hline Observations & 30,268 & 30,268 & 30,268 & 30,268 & 30,268 & 30,268 \\
\hline Adj. $\mathrm{R}^{2}$ & 0.07 & 0.06 & 0.09 & 0.06 & 0.05 & 0.07 \\
\hline
\end{tabular}


Table 2. Volume and Quality of Applications (Cont.)

Panel C: Are Loan Applications in the Treated Group More Likely to Be Approved?

\begin{tabular}{lcccc}
\hline Sample: & \multicolumn{4}{c}{ 2005 Applications } \\
\cline { 2 - 5 } Dependent variable: & \multicolumn{4}{c}{ Application ex ante probability of apporval } \\
\cline { 2 - 5 } & 0.008 & -0.007 & 0.004 & $(3)$ \\
\hline Loan prospecting (0/1) & $(0.018)$ & $(0.019)$ & $(0.019)$ & $(0.0019)$ \\
& & & & \\
Experian business score & & & $0.071^{* * *}$ & $0.076^{* * *}$ \\
& & & $(0.019)$ & $(0.020)$ \\
Experian personal score & & & $0.063^{* * *}$ & $0.094^{* * *}$ \\
& & & $(0.016)$ & $(0.016)$ \\
Internal risk rating & & & $-0.103^{* *}$ & $-0.084^{* *}$ \\
& & & $(0.026)$ & $(0.025)$ \\
log(Requested amount) & & & $-0.049^{* * *}$ & $-0.030^{* * *}$ \\
& & & $(0.008)$ & $(0.008)$ \\
Personal collateral (0/1) & & & 0.070 & 0.050 \\
& & & $(0.086)$ & $(0.087)$ \\
Requested LTV & & & $-0.026^{* * *}$ & $-0.028^{* * *}$ \\
& & & $(0.003)$ & $(0.004)$ \\
Requested LTV & & & $-0.120^{* * *}$ & $-0.117^{* * *}$ \\
& & & $(0.019)$ & $(0.018)$ \\
Loan officer fixed effects & No & Yes & No & Yes \\
Industry fixed effects & Yes & Yes & Yes & Yes \\
Month fixed effects & Yes & Yes & Yes & Yes \\
Observations & & & 15,352 & 15,352 \\
Adj. $\mathrm{R}^{2}$ & 15,352 & 15,352 & 0.15 & 0.17 \\
\hline
\end{tabular}




\section{Table 3. Direct Effects of Loan Prospecting}

The table presents an analysis of the effects of loan prospecting: loan-approval and -origination rates, and average loan size (Panel A), turnaround time and withdrawal rate (Panel B), and default rate (Panel C). All regressions are ordinary least squares regressions. Variables are defined in Appendix A. Standard errors, reported in parentheses, are clustered at the month level. ***,**, and * denote statistical significance at the $1 \%, 5 \%$, and $10 \%$ levels, respectively.

\section{Panel A: Effects on the Extensive and Intensive Margins of Loan Approval and Origination}

\begin{tabular}{|c|c|c|c|c|c|c|c|c|}
\hline \multirow{3}{*}{$\begin{array}{l}\text { Dependent variable: } \\
\text { Sample: }\end{array}$} & \multicolumn{4}{|c|}{$\log (\#$ Loans $)$} & \multicolumn{4}{|c|}{$\log ($ Avg amount $(\$))$} \\
\hline & \multicolumn{2}{|c|}{ Approved } & \multicolumn{2}{|c|}{ Originated } & \multicolumn{2}{|c|}{ Approved } & \multicolumn{2}{|c|}{ Originated } \\
\hline & $(1)$ & $(2)$ & (3) & $(4)$ & $(5)$ & $(6)$ & $(7)$ & $(8)$ \\
\hline Loan prospecting $(0 / 1)$ & $\begin{array}{c}0.282^{* * * *} \\
(0.058)\end{array}$ & $\begin{array}{c}0.313^{* * * *} \\
(0.051)\end{array}$ & $\begin{array}{c}0.276^{* * * *} \\
(0.046)\end{array}$ & $\begin{array}{c}0.305^{* * *} \\
(0.038)\end{array}$ & $\begin{array}{c}0.147^{* * * *} \\
(0.048)\end{array}$ & $\begin{array}{c}0.149^{* * * *} \\
(0.040)\end{array}$ & $\begin{array}{c}0.144 * * * \\
(0.046)\end{array}$ & $\begin{array}{c}0.145^{* * *} \\
(0.043)\end{array}$ \\
\hline Loan officer fixed effects & Yes & Yes & Yes & Yes & Yes & Yes & Yes & Yes \\
\hline Month fixed effects & No & Yes & No & Yes & No & Yes & No & Yes \\
\hline Observations & 3,192 & 3,192 & 3,192 & 3,192 & 3,192 & 3,192 & 3,192 & 3,192 \\
\hline Adj. $\mathrm{R}^{2}$ & 0.15 & 0.17 & 0.19 & 0.20 & 0.13 & 0.15 & 0.16 & 0.17 \\
\hline
\end{tabular}




\section{Table 3. Direct Effects of Loan Prospecting (Cont.)}

\section{Panel B: Turnaround Time and Withdrawal Rate}

\begin{tabular}{|c|c|c|c|c|c|c|}
\hline \multirow{3}{*}{$\begin{array}{l}\text { Dependent variable: } \\
\text { Sample: }\end{array}$} & \multicolumn{4}{|c|}{ \#Months between application and decision } & \multirow{2}{*}{\multicolumn{2}{|c|}{$\frac{\text { I(Application withdrawn) }}{\text { Approved loans }}$}} \\
\hline & \multicolumn{2}{|c|}{ Applications } & \multicolumn{2}{|c|}{ Approved loans } & & \\
\hline & $(1)$ & $(2)$ & (3) & $(4)$ & $(5)$ & $(6)$ \\
\hline Loan prospecting $(0 / 1)$ & $\begin{array}{l}-0.104^{*} \\
(0.056)\end{array}$ & $\begin{array}{l}-0.100^{* *} \\
(0.050)\end{array}$ & $\begin{array}{c}-0.157^{* *} \\
(0.062)\end{array}$ & $\begin{array}{c}0.166^{* * *} \\
(0.064)\end{array}$ & $\begin{array}{c}-0.057^{* *} \\
(0.028)\end{array}$ & $\begin{array}{c}-0.068^{* *} \\
(0.031)\end{array}$ \\
\hline Experian business score & $\begin{array}{c}-0.048^{* * *} \\
(0.017)\end{array}$ & $\begin{array}{c}-0.042^{* * *} \\
(0.016)\end{array}$ & $\begin{array}{c}-0.051 * * * \\
(0.019)\end{array}$ & $\begin{array}{c}-0.049^{* * *} \\
(0.017)\end{array}$ & $\begin{array}{c}0.048 * * * \\
(0.016)\end{array}$ & $\begin{array}{l}0.039^{* *} \\
(0.016)\end{array}$ \\
\hline Experian personal score & $\begin{array}{c}-0.042 * * * \\
(0.014)\end{array}$ & $\begin{array}{c}-0.037 * * \\
(0.014)\end{array}$ & $\begin{array}{c}-0.046 * * * \\
(0.016)\end{array}$ & $\begin{array}{c}-0.043 * * * \\
(0.014)\end{array}$ & $\begin{array}{c}0.039 * * * \\
(0.011)\end{array}$ & $\begin{array}{l}0.028^{* *} \\
(0.014)\end{array}$ \\
\hline $\log ($ Requested amount $)$ & $\begin{array}{c}0.019 * * * \\
(0.007)\end{array}$ & $\begin{array}{c}0.017 * * * \\
(0.006)\end{array}$ & $\begin{array}{c}0.021 * * * \\
(0.007)\end{array}$ & $\begin{array}{c}0.020 * * * \\
(0.007)\end{array}$ & $\begin{array}{c}-0.017 * * * \\
(0.005)\end{array}$ & $\begin{array}{c}-0.020 * * * \\
(0.004)\end{array}$ \\
\hline Personal collateral $(0 / 1)$ & $\begin{array}{l}-0.032 \\
(0.063)\end{array}$ & $\begin{array}{l}-0.030 \\
(0.060)\end{array}$ & $\begin{array}{l}-0.038 \\
(0.066)\end{array}$ & $\begin{array}{l}-0.034 \\
(0.065)\end{array}$ & $\begin{array}{c}0.031 \\
(0.062)\end{array}$ & $\begin{array}{c}0.025 \\
(0.057)\end{array}$ \\
\hline Requested LTV & $\begin{array}{c}0.016^{* * *} \\
(0.003)\end{array}$ & $\begin{array}{c}0.016^{* * *} \\
(0.003)\end{array}$ & $\begin{array}{c}0.019 * * * \\
(0.003)\end{array}$ & $\begin{array}{c}0.017 * * * \\
(0.003)\end{array}$ & $\begin{array}{c}-0.014 * * * \\
(0.002)\end{array}$ & $\begin{array}{c}-0.014 * * * \\
(0.002)\end{array}$ \\
\hline Requested LTV ${ }^{2}$ & $\begin{array}{c}0.068^{* * * *} \\
(0.016)\end{array}$ & $\begin{array}{c}0.068 * * * \\
(0.014)\end{array}$ & $\begin{array}{c}0.079 * * * \\
(0.016)\end{array}$ & $\begin{array}{c}0.070 * * * \\
(0.016)\end{array}$ & $\begin{array}{c}-0.062^{* * *} \\
(0.013)\end{array}$ & $\begin{array}{c}-0.042^{* * * *} \\
(0.014)\end{array}$ \\
\hline Loan officer fixed effects & Yes & Yes & Yes & Yes & Yes & Yes \\
\hline Month fixed effects & No & Yes & No & Yes & No & Yes \\
\hline Observations & 30,268 & 30,268 & 14,359 & 14,359 & 14,359 & 14,359 \\
\hline Adj. $\mathrm{R}^{2}$ & 0.18 & 0.19 & 0.21 & 0.22 & 0.07 & 0.09 \\
\hline
\end{tabular}




\section{Table 4. Did the Bank Approve Applications of Lower Observed Credit Quality?}

The table presents regressions testing whether the lending standards of the Bank changed along with the change in the scope of loan-officer activities. Panel A tests whether a significant difference exists in the credit quality of loans that were approved in the treatment and control groups. Panel A uses only 2005 data, because the calculation of expected default uses 2004 data. Panel B presents an analysis of the effects of loan prospecting on the approval of loans with respect to credit quality. Panel $\mathrm{C}$ tests whether a difference exists in the imputed expected default likelihood of loans that were approved by the treatment and control groups. Imputed predicted default probability is the predicted value from a regression of the default indicator on observable characteristics using the 2004 applications data. Panels B and $\mathrm{C}$ use a sample of all applications. All regressions are ordinary least square regressions. Variables are defined in Appendix A. Standard errors, reported in parentheses, are clustered at the loan-officer level. ***, **, and * denote statistical significance at the $1 \%, 5 \%$, and $10 \%$ levels, respectively.

Panel A: Characteristics of Approved Applications in the Treatment and Control Groups

\begin{tabular}{|c|c|c|c|c|}
\hline \multirow{3}{*}{$\begin{array}{l}\text { Sample: } \\
\text { Dependent variable: }\end{array}$} & \multicolumn{4}{|c|}{ All approved applications } \\
\hline & $\begin{array}{c}\text { Experian } \\
\text { business score } \\
\end{array}$ & $\begin{array}{c}\text { Experian } \\
\text { personal score } \\
\end{array}$ & $\begin{array}{c}\text { Internal } \\
\text { risk rating }\end{array}$ & Interest rate \\
\hline & $\begin{array}{c}(1) \\
\end{array}$ & $\begin{array}{c}(2) \\
\end{array}$ & (3) & (4) \\
\hline \multirow[t]{2}{*}{ Loan prospecting $(0 / 1)$} & 5.333 & 3.129 & 0.045 & 0.007 \\
\hline & $(5.880)$ & $(5.286)$ & $(0.139)$ & $(0.047)$ \\
\hline \multirow[t]{2}{*}{$\log$ (Approved amount) } & $0.041 * *$ & $0.045^{* *}$ & $0.041 * * *$ & $0.049 * * *$ \\
\hline & $(0.016)$ & $(0.020)$ & $(0.016)$ & $(0.019)$ \\
\hline \multirow[t]{2}{*}{ Personal collateral $(0 / 1)$} & $0.018 * * *$ & $0.020 * * *$ & $0.014 * * *$ & $0.022 * * *$ \\
\hline & $(0.006)$ & $(0.006)$ & $(0.005)$ & $(0.007)$ \\
\hline \multirow[t]{2}{*}{ Approved LTV } & $0.037 * * *$ & $0.040 * * *$ & $0.029 * *$ & $0.041 * *$ \\
\hline & $(0.012)$ & $(0.015)$ & $(0.012)$ & $(0.016)$ \\
\hline \multirow[t]{2}{*}{ Approved LTV ${ }^{2}$} & $0.007 * * *$ & $0.008 * * *$ & $0.006 * * *$ & $0.007 * * *$ \\
\hline & $(0.002)$ & $(0.002)$ & $(0.002)$ & $(0.002)$ \\
\hline Loan officer fixed effects & Yes & Yes & Yes & Yes \\
\hline Industry fixed effects & Yes & Yes & Yes & Yes \\
\hline Month fixed effects & Yes & Yes & Yes & Yes \\
\hline Observations & 14,359 & 14,359 & 14,359 & 14,359 \\
\hline Adj. $\mathrm{R}^{2}$ & 0.36 & 0.28 & 0.27 & 0.18 \\
\hline
\end{tabular}


Table 4. Did the Bank Approve Applications of Lower Observed Credit Quality? (Cont.)

\section{Panel B: Focusing on Hard Information}

\begin{tabular}{|c|c|c|c|c|c|c|}
\hline \multirow{3}{*}{$\begin{array}{l}\text { Sample: } \\
\text { Dependent variable: }\end{array}$} & \multicolumn{6}{|c|}{ All applications } \\
\hline & \multicolumn{6}{|c|}{ Application approved (0/1) } \\
\hline & $(1)$ & (2) & (3) & (4) & (5) & (6) \\
\hline Loan prospecting $(0 / 1)$ & $\begin{array}{c}0.074 * * * \\
(0.019)\end{array}$ & $\begin{array}{c}0.084 * * * \\
(0.019)\end{array}$ & $\begin{array}{c}0.049^{* * *} \\
(0.018)\end{array}$ & $\begin{array}{c}0.038^{* *} \\
(0.016)\end{array}$ & $\begin{array}{l}0.037^{* *} \\
(0.017)\end{array}$ & $\begin{array}{l}0.040 * * \\
(0.019)\end{array}$ \\
\hline$\times$ Experian business score & & & $\begin{array}{c}0.019 * * * \\
(0.003)\end{array}$ & $\begin{array}{c}0.015^{* * *} \\
(0.001)\end{array}$ & $\begin{array}{c}0.014^{* * * *} \\
(0.005)\end{array}$ & $\begin{array}{l}0.013^{* *} \\
(0.005)\end{array}$ \\
\hline$\times$ Experian personal score & & & $\begin{array}{c}0.005 \\
(0.003)\end{array}$ & $\begin{array}{l}0.008^{* *} \\
(0.003)\end{array}$ & $\begin{array}{c}0.004 * * * \\
(0.001)\end{array}$ & $\begin{array}{c}0.008 \\
(0.005)\end{array}$ \\
\hline$\times$ Internal risk rating & & & $\begin{array}{c}0.016 \\
(0.014)\end{array}$ & $\begin{array}{c}0.015 \\
(0.011)\end{array}$ & $\begin{array}{c}0.016 \\
(0.012)\end{array}$ & $\begin{array}{c}0.016 \\
(0.011)\end{array}$ \\
\hline Experian business score & & & & & $\begin{array}{c}0.003 \\
(0.010)\end{array}$ & $\begin{array}{c}0.016^{* * * *} \\
(0.006)\end{array}$ \\
\hline Experian personal score & & & & & $\begin{array}{l}0.006^{* *} \\
(0.003)\end{array}$ & $\begin{array}{c}0.013^{* * *} \\
(0.003)\end{array}$ \\
\hline Internal risk rating & & & & & $\begin{array}{c}-0.026^{* * * *} \\
(0.006)\end{array}$ & $\begin{array}{c}-0.024^{* * *} \\
(0.005)\end{array}$ \\
\hline $\log ($ Requested amount) & & & & & $\begin{array}{c}0.005 * * * \\
(0.001)\end{array}$ & $\begin{array}{c}0.004 \\
(0.004)\end{array}$ \\
\hline Personal collateral $(0 / 1)$ & & & & & $\begin{array}{c}0.011 \\
(0.037)\end{array}$ & $\begin{array}{c}0.008 \\
(0.015)\end{array}$ \\
\hline Requested LTV & & & & & $\begin{array}{c}-0.008 * * * \\
(0.000)\end{array}$ & $\begin{array}{l}-0.002 \\
(0.002)\end{array}$ \\
\hline Requested LTV ${ }^{2}$ & & & & & $\begin{array}{c}-0.032 * * * \\
(0.005)\end{array}$ & $\begin{array}{c}-0.018^{* * * *} \\
(0.003)\end{array}$ \\
\hline Loan officer fixed effects & No & Yes & No & Yes & No & Yes \\
\hline Industry fixed effects & Yes & Yes & Yes & Yes & Yes & Yes \\
\hline Month fixed effects & Yes & Yes & Yes & Yes & Yes & Yes \\
\hline Observations & 30,268 & 30,268 & 30,268 & 30,268 & 30,268 & 30,268 \\
\hline Adj. $\mathrm{R}^{2}$ & 0.14 & 0.14 & 0.15 & 0.15 & 0.15 & 0.15 \\
\hline
\end{tabular}


Table 4. Did the Bank Approve Applications of Lower Observed Credit Quality? (Cont.)

Panel C: Predicted Default Probability in the Treatment and Control Groups in 2005

\begin{tabular}{|c|c|c|c|}
\hline \multirow{3}{*}{$\begin{array}{l}\text { Sample: } \\
\text { Dependent variable: }\end{array}$} & \multirow{2}{*}{$\begin{array}{c}\text { All } 2005 \text { applications } \\
\text { Application approved }(0 / 1)\end{array}$} & \multicolumn{2}{|c|}{ All 2005 approved loans } \\
\hline & & $\log ($ Loan amount $)$ & Interest rate \\
\hline & $(1)$ & $(2)$ & (3) \\
\hline \multirow[t]{2}{*}{ Imputed predicted default likelihood } & $-0.024 * *$ & $-0.027 * *$ & $0.047 * *$ \\
\hline & $(0.011)$ & $(0.011)$ & $(0.022)$ \\
\hline \multirow[t]{2}{*}{$\times$ Loan prospecting $(0 / 1)$} & 0.003 & $0.056^{* *}$ & $0.054 * *$ \\
\hline & $(0.009)$ & $(0.025)$ & $(0.025)$ \\
\hline \multirow[t]{2}{*}{ Loan prospecting $(0 / 1)$} & $0.027 * *$ & 0.017 & $0.037^{*}$ \\
\hline & $(0.012)$ & $(0.013)$ & $(0.023)$ \\
\hline Loan officer fixed effects & No & No & No \\
\hline Industry fixed effects & Yes & Yes & Yes \\
\hline Month fixed effects & No & No & No \\
\hline Observations & 15,352 & 8,485 & 8,485 \\
\hline Adj. $\mathrm{R}^{2}$ & 0.21 & 0.07 & 0.14 \\
\hline
\end{tabular}




\section{Table 5. Default Rates}

The table presents an analysis of the default rates following the loan-prospecting experiment. All regressions are ordinary least squares regressions. Variables are defined in Appendix A. Standard errors, reported in parentheses, are clustered at the month level. $* * *, * *$, and * denote statistical significance at the $1 \%, 5 \%$, and $10 \%$ levels, respectively.

\begin{tabular}{lcccc}
\hline Sample: & \multicolumn{4}{c}{ All originated loans } \\
\cline { 2 - 5 } Dependent variable: & \multicolumn{4}{c}{ Defaulted within 12 months $(0 / 1)$} \\
\cline { 2 - 5 } & $0.012^{* * *}$ & $0.012^{* * *}$ & $0.012^{* * *}$ & $0.011^{* * *}$ \\
\hline Loan prospecting (0/1) & $(0.003)$ & $(0.003)$ & $(0.004)$ & $(0.003)$ \\
& & & $0.039^{* * *}$ & $0.035^{* *}$ \\
Interest rate (\%) & & & $(0.014)$ & $(0.014)$ \\
& & & & \\
Loan officer fixed effects & Yes & Yes & Yes & Yes \\
Industry fixed effects & No & Yes & No & Yes \\
Month fixed effects & No & Yes & No & Yes \\
& & & & \\
Observations & 11,164 & 11,164 & 11,164 & 11,164 \\
Adj. $\mathrm{R}^{2}$ & 0.21 & 0.21 & 0.23 & 0.23 \\
\hline
\end{tabular}




\section{Table 6. Default Drivers: Extensive and Intensive Margins}

The table explores the relation between loan amount and loan performance. All regressions are ordinary least square regressions. Variables are defined in Appendix A. Standard errors, reported in parentheses, are clustered at the loanofficer level. ${ }^{* * *}, * *$, and $*$ denote statistical significance at the $1 \%, 5 \%$, and $10 \%$ levels, respectively.

\begin{tabular}{|c|c|c|c|c|c|}
\hline \multirow{3}{*}{$\begin{array}{r}\text { Sample: } \\
\text { Dependent variable: }\end{array}$} & \multicolumn{5}{|c|}{ All originated loans } \\
\hline & \multicolumn{5}{|c|}{ Defaulted within 12 months $(0 / 1)$} \\
\hline & $(1)$ & $(2)$ & (3) & $(4)$ & $(5)$ \\
\hline Loan prospecting $(0 / 1)$ & $\begin{array}{c}0.013 * * * \\
(0.004)\end{array}$ & $\begin{array}{c}0.067 * * * \\
(0.003)\end{array}$ & $\begin{array}{c}0.055 * * * \\
(0.002)\end{array}$ & $\begin{array}{c}0.066^{* * *} \\
(0.002)\end{array}$ & $\begin{array}{c}0.030^{* * *} \\
(0.002)\end{array}$ \\
\hline$\times$ Loan approved (residual) & & $\begin{array}{c}0.040^{* * *} \\
(0.015)\end{array}$ & & & $\begin{array}{c}0.036^{* * *} \\
(0.014)\end{array}$ \\
\hline$\times$ I(Amount approved $>$ Amount requested $)$ & & & $\begin{array}{c}0.038^{* * * *} \\
(0.010)\end{array}$ & & $\begin{array}{c}0.034^{* * * *} \\
(0.011)\end{array}$ \\
\hline × Originated LTV (residual) & & & & $\begin{array}{c}0.034^{* *} \\
(0.013)\end{array}$ & $\begin{array}{c}0.034 * * \\
(0.015)\end{array}$ \\
\hline Loan approved (residual) & & $\begin{array}{c}0.027^{* *} \\
(0.014)\end{array}$ & & & $\begin{array}{l}0.026^{*} \\
(0.015)\end{array}$ \\
\hline I(Amount approved $>$ Amount requested) & & & $\begin{array}{l}0.028^{* *} \\
(0.012)\end{array}$ & & $\begin{array}{c}0.026^{* *} \\
(0.012)\end{array}$ \\
\hline Originated LTV (residual) & & & & $\begin{array}{c}0.037 * * \\
(0.015)\end{array}$ & $\begin{array}{c}0.035^{* *} \\
(0.014)\end{array}$ \\
\hline $\log ($ Originated loan amount) & $\begin{array}{c}0.077 * * * \\
(0.022)\end{array}$ & $\begin{array}{c}0.082 * * * \\
(0.027)\end{array}$ & $\begin{array}{c}0.029 \\
(0.022)\end{array}$ & $\begin{array}{c}0.078 * * * \\
(0.025)\end{array}$ & $\begin{array}{c}0.007 \\
(0.019)\end{array}$ \\
\hline Personal collateral $(0 / 1)$ & $\begin{array}{l}-0.038 \\
(0.033)\end{array}$ & $\begin{array}{l}-0.059 \\
(0.043)\end{array}$ & $\begin{array}{l}-0.055 \\
(0.034)\end{array}$ & $\begin{array}{l}-0.045 \\
(0.035)\end{array}$ & $\begin{array}{l}-0.043 \\
(0.028)\end{array}$ \\
\hline Experian business score & $\begin{array}{l}-0.001 \\
(0.001)\end{array}$ & $\begin{array}{l}-0.001^{*} \\
(0.001)\end{array}$ & $\begin{array}{l}-0.001 \\
(0.001)\end{array}$ & $\begin{array}{l}-0.001 \\
(0.001)\end{array}$ & $\begin{array}{l}-0.001 \\
(0.001)\end{array}$ \\
\hline Experian personal score & $\begin{array}{l}-0.001 \\
(0.001)\end{array}$ & $\begin{array}{l}-0.001 \\
(0.001)\end{array}$ & $\begin{array}{l}-0.001 \\
(0.001)\end{array}$ & $\begin{array}{l}-0.001 \\
(0.001)\end{array}$ & $\begin{array}{l}-0.001 \\
(0.001)\end{array}$ \\
\hline Originated LTV & $\begin{array}{c}0.014 * * \\
(0.006)\end{array}$ & $\begin{array}{l}0.013 * * \\
(0.006)\end{array}$ & $\begin{array}{l}0.016^{* *} \\
(0.007)\end{array}$ & & $\begin{array}{c}0.012 * * * \\
(0.004)\end{array}$ \\
\hline Originated LTV ${ }^{2}$ & $\begin{array}{c}0.035^{* * *} \\
(0.002)\end{array}$ & $\begin{array}{c}0.036^{* * *} \\
(0.002)\end{array}$ & $\begin{array}{c}0.033 * * * \\
(0.002)\end{array}$ & & $\begin{array}{c}0.031^{* * * *} \\
(0.002)\end{array}$ \\
\hline Interest rate $(\%)$ & $\begin{array}{c}0.038^{* * * *} \\
(0.013)\end{array}$ & $\begin{array}{c}0.051^{* * * *} \\
(0.012)\end{array}$ & $\begin{array}{c}0.048 * * * \\
(0.014)\end{array}$ & $\begin{array}{c}0.039 * * * \\
(0.012)\end{array}$ & $\begin{array}{c}0.044 * * * \\
(0.019)\end{array}$ \\
\hline Loan officer fixed effects & Yes & Yes & Yes & Yes & Yes \\
\hline Industry fixed effects & Yes & Yes & Yes & Yes & Yes \\
\hline Month fixed effects & Yes & Yes & Yes & Yes & Yes \\
\hline Observations & 11,164 & 11,164 & 11,164 & 11,164 & 11,164 \\
\hline Adj. $R^{2}$ & 0.21 & 0.23 & 0.21 & 0.23 & 0.26 \\
\hline
\end{tabular}




\section{Table 7. Performance Driver: Breakdown of the Credit Model}

The table tests the hypothesis that the Bank's credit model broke down during the loan-prospecting experiment. Panel A tests whether default is correlated with different information types. Panel B tests whether default is correlated with predicted default in the control and in the treatment groups. All regressions are ordinary least square regressions. Variables are defined in Appendix A. Standard errors, reported in parentheses, are clustered at the loan-officer level. $* * *, * *$, and $*$ denote statistical significance at the $1 \%, 5 \%$, and $10 \%$ levels, respectively.

\section{Panel A: Information Types and Default}

\begin{tabular}{|c|c|c|c|c|c|c|}
\hline \multirow{3}{*}{$\begin{array}{l}\text { Sample: } \\
\text { Dependent variable: }\end{array}$} & \multicolumn{6}{|c|}{ All originated loans } \\
\hline & \multicolumn{6}{|c|}{ Defaulted within 12 months $(0 / 1)$} \\
\hline & $(1)$ & $(2)$ & (3) & $(4)$ & $(5)$ & $(6)$ \\
\hline Loan prospecting $(0 / 1)$ & $\begin{array}{c}0.014 * * * \\
(0.004)\end{array}$ & $\begin{array}{c}0.012^{* * * *} \\
(0.003)\end{array}$ & $\begin{array}{l}0.012^{* *} \\
(0.002)\end{array}$ & $\begin{array}{l}0.012^{* *} \\
(0.002)\end{array}$ & $\begin{array}{c}0.049^{* * * *} \\
(0.002)\end{array}$ & $\begin{array}{l}0.006^{* *} \\
(0.002)\end{array}$ \\
\hline$\times$ Experian business score & & & $\begin{array}{c}0.030^{* * * *} \\
(0.004)\end{array}$ & $\begin{array}{c}0.021^{* * *} \\
(0.006)\end{array}$ & $\begin{array}{c}0.029^{* * *} \\
(0.006)\end{array}$ & $\begin{array}{l}0.017^{*} \\
(0.010)\end{array}$ \\
\hline$\times$ Experian personal score & & & $\begin{array}{c}0.011 \\
(0.008)\end{array}$ & $\begin{array}{c}0.014^{* * *} \\
(0.005)\end{array}$ & $\begin{array}{l}0.009^{*} \\
(0.005)\end{array}$ & $\begin{array}{c}0.011 \\
(0.009)\end{array}$ \\
\hline$\times$ Internal risk rating & & & $\begin{array}{c}0.026^{* * *} \\
(0.006)\end{array}$ & $\begin{array}{l}0.019^{* *} \\
(0.009)\end{array}$ & $\begin{array}{c}0.031^{* * *} \\
(0.009)\end{array}$ & $\begin{array}{c}0.032 * * * \\
(0.009)\end{array}$ \\
\hline Experian business score & & & $\begin{array}{l}-0.020 \\
(0.015)\end{array}$ & $\begin{array}{l}-0.018 \\
(0.014)\end{array}$ & $\begin{array}{l}-0.020 \\
(0.016)\end{array}$ & $\begin{array}{l}-0.019 \\
(0.014)\end{array}$ \\
\hline Experian personal score & & & $\begin{array}{c}-0.016^{* *} \\
(0.008)\end{array}$ & $\begin{array}{l}-0.017^{*} \\
(0.010)\end{array}$ & $\begin{array}{c}-0.017^{* *} \\
(0.008)\end{array}$ & $\begin{array}{l}-0.018^{*} \\
(0.010)\end{array}$ \\
\hline Internal risk rating & & & $\begin{array}{c}0.037 * * * \\
(0.014)\end{array}$ & $\begin{array}{c}0.032 \\
(0.020)\end{array}$ & $\begin{array}{c}0.039 * * * \\
(0.014)\end{array}$ & $\begin{array}{c}0.033 \\
(0.021)\end{array}$ \\
\hline $\log ($ Requested amount $)$ & & & & & $\begin{array}{c}0.014 * * * \\
(0.003)\end{array}$ & $\begin{array}{c}0.016^{* * *} \\
(0.005)\end{array}$ \\
\hline Personal collateral $(0 / 1)$ & & & & & $\begin{array}{l}-0.021 \\
(0.048)\end{array}$ & $\begin{array}{l}-0.024 \\
(0.042)\end{array}$ \\
\hline Requested LTV & & & & & $\begin{array}{c}0.010 * * * \\
(0.002)\end{array}$ & $\begin{array}{c}0.010^{* * *} \\
(0.002)\end{array}$ \\
\hline Requested $\mathrm{LTV}^{2}$ & & & & & $\begin{array}{c}0.050 * * * \\
(0.009)\end{array}$ & $\begin{array}{c}0.047 * * * \\
(0.008)\end{array}$ \\
\hline Loan officer fixed effects & No & Yes & No & Yes & No & Yes \\
\hline Industry fixed effects & Yes & Yes & Yes & Yes & Yes & Yes \\
\hline Month fixed effects & Yes & Yes & Yes & Yes & Yes & Yes \\
\hline Observations & 11,164 & 11,164 & 11,164 & 11,164 & 11,164 & 11,164 \\
\hline Adj. $R^{2}$ & 0.21 & 0.21 & 0.23 & 0.25 & 0.26 & 0.27 \\
\hline
\end{tabular}


Table 7. Performance Driver: Breakdown of the Credit Model (Cont.)

\section{Panel B: Predicted Default Likelihood and Actual Default}

\begin{tabular}{|c|c|c|c|}
\hline Sample: & $\begin{array}{c}2005 \text { Originated loans } \\
\text { (Group A) }\end{array}$ & $\begin{array}{l}2005 \text { Originated loans } \\
\text { (Group B) }\end{array}$ & All 2005 Originated loans \\
\hline \multirow[t]{2}{*}{ Dependent variable: } & Default $(0 / 1)$ & Default $(0 / 1)$ & Default $(0 / 1)$ \\
\hline & $(1)$ & $(2)$ & (3) \\
\hline Loan prospecting $(0 / 1)$ & & & $\begin{array}{c}0.010^{* * * *} \\
(0.004)\end{array}$ \\
\hline$\times$ Predicted default likelihood & & & $\begin{array}{c}-0.015^{* * *} \\
(0.006)\end{array}$ \\
\hline$\times$ Internal risk rating & & & $\begin{array}{c}0.010^{* *} \\
(0.005)\end{array}$ \\
\hline$\times$ Interest rate & & & $\begin{array}{c}-0.019 * * * \\
(0.003)\end{array}$ \\
\hline Predicted default likelihood & $\begin{array}{l}0.022 * * \\
(0.009)\end{array}$ & $\begin{array}{c}0.003 \\
(0.006)\end{array}$ & $\begin{array}{l}0.022^{* *} \\
(0.009)\end{array}$ \\
\hline Internal risk rating & $\begin{array}{l}-0.015^{*} \\
(0.008)\end{array}$ & $\begin{array}{l}-0.002 \\
(0.005)\end{array}$ & $\begin{array}{l}-0.014^{*} \\
(0.008)\end{array}$ \\
\hline Interest rate & $\begin{array}{c}0.043 * * * \\
(0.004)\end{array}$ & $\begin{array}{c}0.024 * * * \\
(0.004)\end{array}$ & $\begin{array}{c}0.046^{* * *} \\
(0.003)\end{array}$ \\
\hline Loan officer fixed effects & Yes & Yes & Yes \\
\hline Industry fixed effects & Yes & Yes & Yes \\
\hline Month fixed effects & Yes & Yes & Yes \\
\hline Observations & 2,744 & 3,680 & 6,424 \\
\hline Adj. $R^{2}$ & 0.09 & 0.09 & 0.10 \\
\hline
\end{tabular}




\section{Table 7. Breakdown of the Credit Model (Cont.)}

\section{Panel C: Predicted Default Likelihood and Non-“normative" Lending}

\begin{tabular}{|c|c|c|c|c|}
\hline \multirow[t]{4}{*}{ Sample: } & \multicolumn{4}{|c|}{2005 Originated loans, where... } \\
\hline & \multirow{3}{*}{$\begin{array}{c}\mathrm{I}(\$ \text { Approved } \leq \$ \text { Requested }) \\
\text { (Less aggressive) }\end{array}$} & \multirow{3}{*}{$\begin{array}{c}\text { I }\left(\begin{array}{c}\text { Approved }>\$ \text { Requested }) \\
(\text { Aggressive })\end{array}\right. \\
\end{array}$} & \multicolumn{2}{|c|}{ Residual(log(loan amount)) } \\
\hline & & & $\leq 1 \mathrm{StDev}$ & $>1 \mathrm{StDev}$ \\
\hline & & & (Less aggressive) & (Aggressive) \\
\hline \multirow[t]{2}{*}{ Dependent variable: } & Default $(0 / 1)$ & Default $(0 / 1)$ & Default $(0 / 1)$ & Default $(0 / 1)$ \\
\hline & (1) & (2) & (3) & (4) \\
\hline \multirow[t]{2}{*}{ Loan prospecting $(0 / 1)$} & $0.010^{* *}$ & 0.008 & 0.009 & 0.012 \\
\hline & $(0.005)$ & $(0.007)$ & $(0.006)$ & $(0.008)$ \\
\hline \multirow[t]{2}{*}{$\times$ Predicted default likelihood } & -0.007 & $-0.016^{* *}$ & -0.004 & $-0.015^{* *}$ \\
\hline & $(0.005)$ & $(0.008)$ & $(0.006)$ & $(0.007)$ \\
\hline \multirow[t]{2}{*}{$\times$ Internal risk rating } & 0.007 & 0.008 & 0.004 & 0.008 \\
\hline & $(0.010)$ & $(0.009)$ & $(0.008)$ & $(0.013)$ \\
\hline \multirow[t]{2}{*}{$\times$ Interest rate } & -0.014 & -0.013 & -0.008 & $-0.019^{*}$ \\
\hline & $(0.019)$ & $(0.017)$ & $(0.019)$ & $(0.011)$ \\
\hline \multirow[t]{2}{*}{ Predicted default likelihood } & $0.019 * *$ & $0.015^{*}$ & $0.015^{* *}$ & $0.018^{* * *}$ \\
\hline & $(0.009)$ & $(0.008)$ & $(0.006)$ & $(0.005)$ \\
\hline \multirow[t]{2}{*}{ Internal risk rating } & $-0.013 *$ & $-0.015^{* *}$ & -0.009 & $-0.016^{* *}$ \\
\hline & $(0.007)$ & $(0.007)$ & $(0.007)$ & $(0.007)$ \\
\hline \multirow[t]{2}{*}{ Interest rate } & $0.046 * * *$ & $0.038 * * *$ & $0.035 * * *$ & $0.045 * * *$ \\
\hline & $(0.003)$ & $(0.008)$ & $(0.003)$ & $(0.003)$ \\
\hline Loan officer fixed effects & Yes & Yes & Yes & Yes \\
\hline Industry fixed effects & Yes & Yes & Yes & Yes \\
\hline Month fixed effects & Yes & Yes & Yes & Yes \\
\hline Observations & 5,525 & 899 & 3,195 & 3,229 \\
\hline Adj. $\mathrm{R}^{2}$ & 0.09 & 0.07 & 0.07 & 0.06 \\
\hline
\end{tabular}




\section{Table 8. Loan-Officer Characteristics and Loan Origination}

The table tests the relation between loan-officer characteristics (tenure, gender) and the loan-origination process. Panel A tests the relation between the likelihood of loan approval and loan-officer characteristics (columns (1) to (4)), and the relation between loan amounts and loan-officer characteristics (columns (5) to (8)). Panel B tests the relation between loan officers' compensation and loan-officer characteristics. All regressions are ordinary least square regressions. Variables are defined in Appendix A. Standard errors, reported in parentheses, are clustered at the loanofficer level. $* * *, * *$, and $*$ denote statistical significance at the $1 \%, 5 \%$, and $10 \%$ levels, respectively.

\section{Panel A: Loan-Officer Characteristics and Decision-Making}

\begin{tabular}{|c|c|c|c|c|c|c|c|c|}
\hline \multirow[t]{2}{*}{ Dependent variable: } & \multicolumn{4}{|c|}{ Approved loan $(0 / 1)$} & \multicolumn{4}{|c|}{$\log ($ Loan amount $)$} \\
\hline & $(1)$ & $(2)$ & $(3)$ & $(4)$ & $(5)$ & $(6)$ & $(7)$ & $(8)$ \\
\hline Loan prospecting $(0 / 1)$ & $\begin{array}{c}0.054^{* * *} \\
(0.018)\end{array}$ & $\begin{array}{c}0.033^{* * *} \\
(0.006)\end{array}$ & $\begin{array}{c}0.041^{* * * *} \\
(0.002)\end{array}$ & $\begin{array}{c}0.052^{* * *} \\
(0.006)\end{array}$ & $\begin{array}{c}0.103 * * * \\
(0.010)\end{array}$ & $\begin{array}{c}0.058^{* * *} \\
(0.010)\end{array}$ & $\begin{array}{c}0.032^{* * * *} \\
(0.011)\end{array}$ & $\begin{array}{l}0.023^{* *} \\
(0.010)\end{array}$ \\
\hline$\times$ Tenure above median $(0 / 1)$ & & $\begin{array}{c}0.025^{* *} \\
(0.009)\end{array}$ & & $\begin{array}{c}0.005^{*} \\
(0.003)\end{array}$ & & $\begin{array}{l}0.051^{* *} \\
(0.025)\end{array}$ & & $\begin{array}{c}0.054^{* * * *} \\
(0.017)\end{array}$ \\
\hline$\times$ Male $(0 / 1)$ & & & $\begin{array}{c}0.020^{* * * *} \\
(0.001)\end{array}$ & $\begin{array}{c}0.003 \\
(0.003)\end{array}$ & & & $\begin{array}{c}0.070^{* * * *} \\
(0.023)\end{array}$ & $\begin{array}{l}0.050^{* *} \\
(0.018)\end{array}$ \\
\hline Tenure above median $(0 / 1)$ & & $\begin{array}{c}0.003 \\
(0.002)\end{array}$ & & $\begin{array}{c}0.004 \\
(0.013)\end{array}$ & & $\begin{array}{c}0.002 \\
(0.012)\end{array}$ & & $\begin{array}{c}0.003 \\
(0.002)\end{array}$ \\
\hline Male $(0 / 1)$ & & & $\begin{array}{c}0.002 \\
(0.002)\end{array}$ & $\begin{array}{c}0.005^{* *} \\
(0.002)\end{array}$ & & & $\begin{array}{c}0.005^{* *} \\
(0.002)\end{array}$ & $\begin{array}{c}0.001 \\
(0.004)\end{array}$ \\
\hline Experian business score & $\begin{array}{c}0.003 \\
(0.002)\end{array}$ & $\begin{array}{c}0.003 \\
(0.005)\end{array}$ & $\begin{array}{c}0.004 \\
(0.004)\end{array}$ & $\begin{array}{c}0.006^{* * *} \\
(0.002)\end{array}$ & $\begin{array}{c}0.001 \\
(0.002)\end{array}$ & $\begin{array}{c}0.002 \\
(0.003)\end{array}$ & $\begin{array}{c}0.004 \\
(0.009)\end{array}$ & $\begin{array}{c}0.007^{* * *} \\
(0.000)\end{array}$ \\
\hline Experian personal score & $\begin{array}{c}0.005^{* * *} \\
(0.000)\end{array}$ & $\begin{array}{c}0.008^{* * *} \\
(0.001)\end{array}$ & $\begin{array}{c}0.010^{* * *} \\
(0.002)\end{array}$ & $\begin{array}{c}0.008^{* * *} \\
(0.000)\end{array}$ & $\begin{array}{c}0.003^{* * * *} \\
(0.001)\end{array}$ & $\begin{array}{c}0.001 \\
(0.001)\end{array}$ & $\begin{array}{c}0.004 * * \\
(0.002)\end{array}$ & $\begin{array}{c}0.006^{* * *} \\
(0.000)\end{array}$ \\
\hline Internal risk rating & $\begin{array}{c}0.008 * * * \\
(0.000)\end{array}$ & $\begin{array}{c}0.004 \\
(0.008)\end{array}$ & $\begin{array}{c}0.005 \\
(0.008)\end{array}$ & $\begin{array}{c}0.003 \\
(0.007)\end{array}$ & $\begin{array}{c}0.006 \\
(0.007)\end{array}$ & $\begin{array}{c}0.004 * * * \\
(0.000)\end{array}$ & $\begin{array}{c}0.002 \\
(0.009)\end{array}$ & $\begin{array}{c}0.001 \\
(0.002)\end{array}$ \\
\hline $\log ($ Requested amount $)$ & $\begin{array}{c}0.000 \\
(0.000)\end{array}$ & $\begin{array}{c}0.001 \\
(0.004)\end{array}$ & $\begin{array}{c}0.001 \\
(0.001)\end{array}$ & $\begin{array}{c}0.001 \\
(0.004)\end{array}$ & $\begin{array}{c}0.877^{* * *} \\
(0.123)\end{array}$ & $\begin{array}{c}0.857^{* * *} \\
(0.122)\end{array}$ & $\begin{array}{c}0.878^{* * *} \\
(0.121)\end{array}$ & $\begin{array}{c}0.860^{* * *} \\
(0.120)\end{array}$ \\
\hline Personal collateral $(0 / 1)$ & $\begin{array}{c}0.002 \\
(0.026)\end{array}$ & $\begin{array}{c}0.005 \\
(0.004)\end{array}$ & $\begin{array}{c}0.001 \\
(0.025)\end{array}$ & $\begin{array}{c}0.005 \\
(0.014)\end{array}$ & $\begin{array}{c}0.010 \\
(0.018)\end{array}$ & $\begin{array}{c}0.005 \\
(0.008)\end{array}$ & $\begin{array}{c}0.007 \\
(0.028)\end{array}$ & $\begin{array}{c}0.002 \\
(0.001)\end{array}$ \\
\hline Requested LTV & $\begin{array}{l}-0.000 \\
(0.000)\end{array}$ & $\begin{array}{l}-0.002 \\
(0.001)\end{array}$ & $\begin{array}{c}-0.001^{* * * *} \\
(0.000)\end{array}$ & $\begin{array}{c}-0.002 * * * \\
(0.000)\end{array}$ & $\begin{array}{c}-0.006^{* * *} \\
(0.000)\end{array}$ & $\begin{array}{l}-0.000^{*} \\
(0.000)\end{array}$ & $\begin{array}{c}-0.005^{* * *} \\
(0.000)\end{array}$ & $\begin{array}{c}-0.002^{* * *} \\
(0.000)\end{array}$ \\
\hline Requested LTV ${ }^{2}$ & $\begin{array}{l}-0.001 \\
(0.002)\end{array}$ & $\begin{array}{c}-0.006^{* * *} \\
(0.002)\end{array}$ & $\begin{array}{c}-0.003 \\
(0.004)\end{array}$ & $\begin{array}{c}-0.008^{* * *} \\
(0.002)\end{array}$ & $\begin{array}{c}-0.002 * * * \\
(0.000)\end{array}$ & $\begin{array}{l}-0.003 \\
(0.003)\end{array}$ & $\begin{array}{c}-0.004 * * \\
(0.002)\end{array}$ & $\begin{array}{c}-0.001 \\
(0.001)\end{array}$ \\
\hline Industry fixed effects & Yes & Yes & Yes & Yes & Yes & Yes & Yes & Yes \\
\hline Month fixed effects & Yes & Yes & Yes & Yes & Yes & Yes & Yes & Yes \\
\hline Observations & 30,268 & 30,268 & 30,268 & 30,268 & 14,916 & 14,916 & 14,916 & 14,916 \\
\hline Adj. $\mathrm{R}^{2}$ & 0.28 & 0.28 & 0.29 & 0.29 & 0.41 & 0.41 & 0.42 & 0.42 \\
\hline
\end{tabular}


Table 8. Loan-Officer Characteristics and Loan Origination (Cont.)

Panel B: Loan-Officer Characteristics and Compensation

\begin{tabular}{lcccc}
\hline Dependent variable: & \multicolumn{4}{c}{$\log ($ Compensation $(\$))$} \\
\cline { 2 - 5 } & $0.082^{* * *}$ & $0.075^{* * *}$ & $0.066^{* * *}$ & $0.060^{* * *}$ \\
\hline Loan prospecting (0/1) & $(0.020)$ & $(0.014)$ & $(0.016)$ & $(0.015)$ \\
$\times$ Tenure above median (0/1) & & $0.025^{* *}$ & & $0.021^{* *}$ \\
& & $(0.011)$ & & $(0.011)$ \\
$\times$ Male (0/1) & & $0.036^{* * *}$ & $0.038^{* * *}$ \\
& & & $(0.011)$ & $(0.010)$ \\
Tenure above median $(0 / 1)$ & & 0.006 & & 0.005 \\
& & $(0.014)$ & & $(0.014)$ \\
Male (0/1) & & & 0.007 & 0.006 \\
& & & $(0.012)$ & $(0.011)$ \\
Month fixed effects & Yes & Yes & Yes & Yes \\
Observations & 3,192 & 3,192 & 3,192 & 3,192 \\
Adj. $\mathrm{R}^{2}$ & 0.54 & 0.57 & 0.69 & 0.70 \\
\hline
\end{tabular}




\section{Figure 1. Approval Rate (Residual) over Time and across Groups}

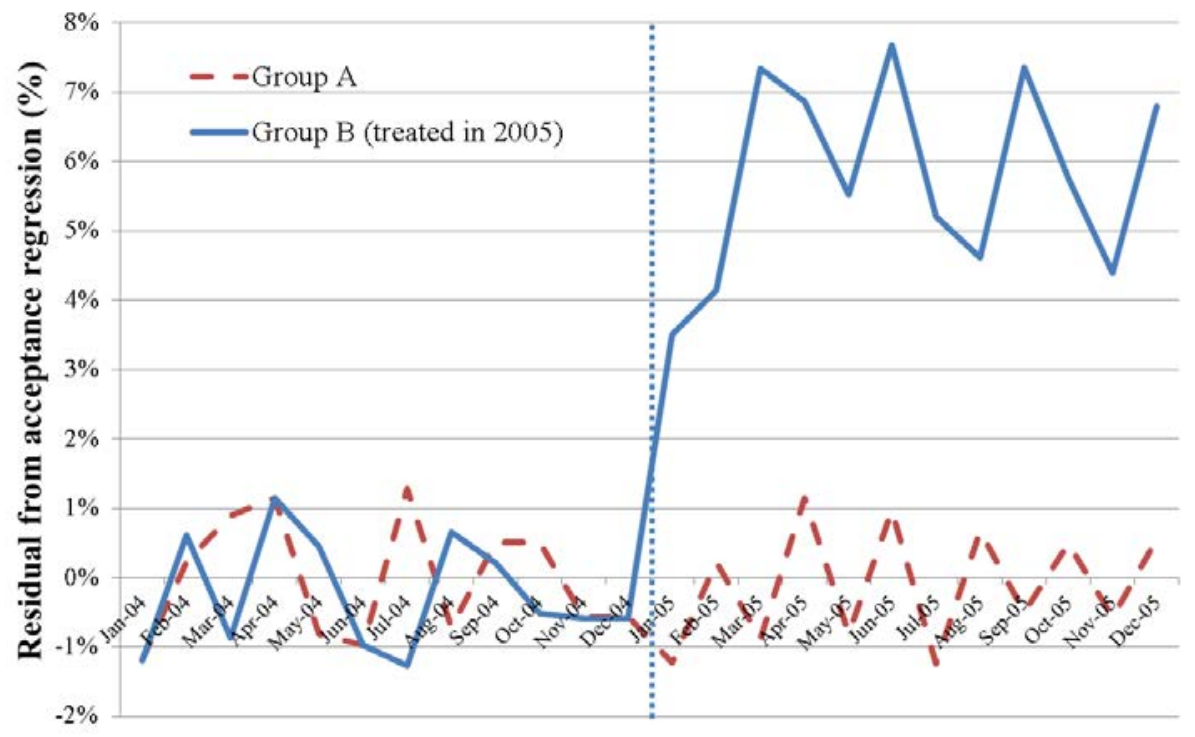

The chart shows the average residual from the approval regression (see Appendix C). The residuals are averaged within group (Groups A and B) and month. Note that whereas the regression uses only the control sample, the residuals are calculated for the entire sample and therefore do not have a mean of zero. 
Figure 2. Average Originated Loan Amount over Time and across Groups

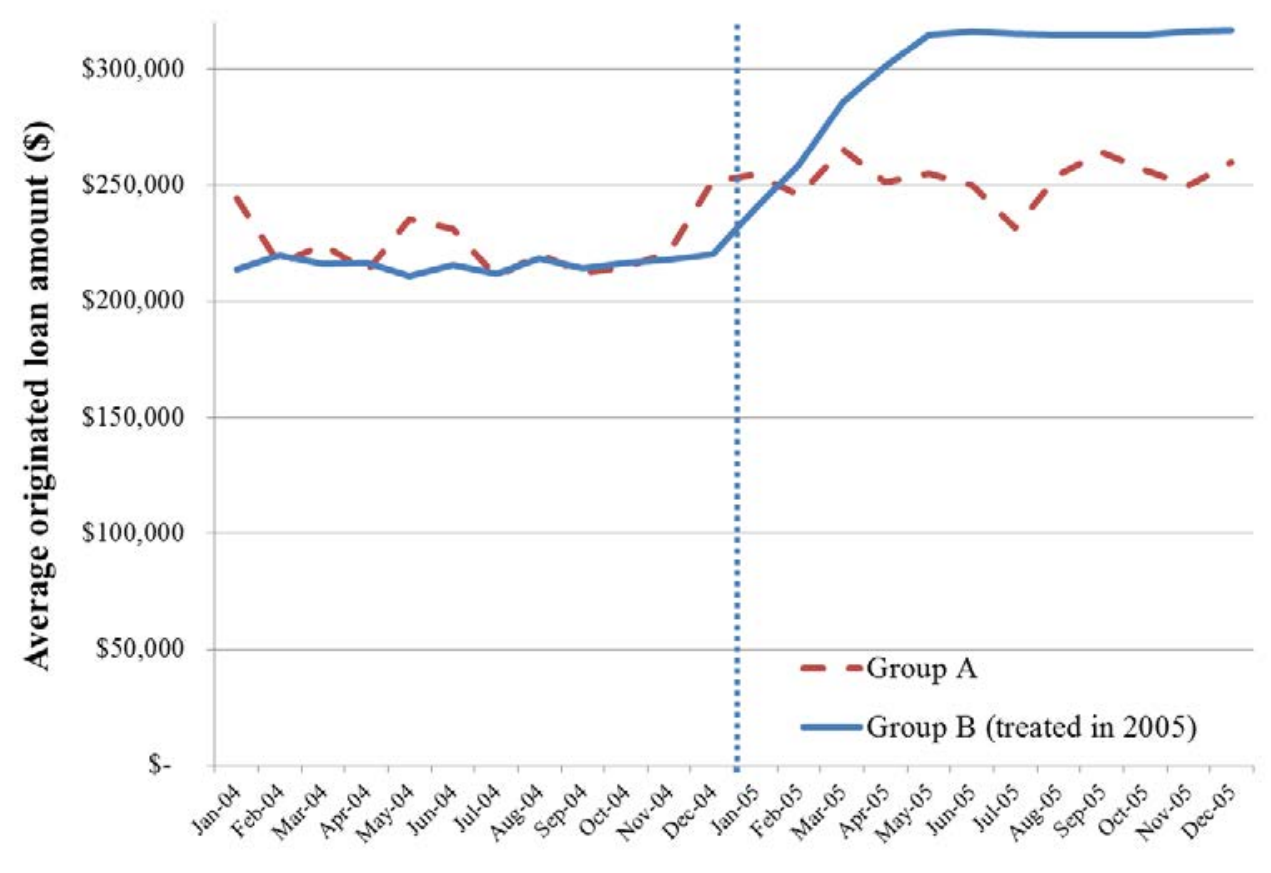

The chart shows the average loan size. Loan sizes are averaged within group (Groups A and B) and month. 